AGATA GABIŚ

Instytut Historyczny Uniwersytetu Wrocławskiego

\title{
OSIEDLE IDEALNE CZY PERYFERYJNE SIEDLISKO? OKOLICZNOŚCI POWSTANIA I ANALIZA ZAEOŻENIA PRZESTRZENNO-ARCHITEKTONICZNEGO WROCŁAWSKICH KUŹNIK
}

Zarys treści: Analiza okoliczności powstania wrocławskiego osiedla Kuźniki pozwala poznać fragment powojennej historii miasta, które po 1970 r. zaczęło rozrastać się w kierunku zachodnim. Sytuacja ekonomiczna i polityczna determinowała w dużym stopniu ówczesną architekturę i urbanistykę, jednak na tle innych, wielkoskalowych realizacji tego czasu kameralne osiedle Kuźniki odznacza się indywidualnym podejściem do kształtowania formy plastycznej oraz powiązaniem kompozycji urbanistycznej z krajobrazem.

The content outline: The analysis of the circumstances of the creation of Wrocław's Kuźniki housing estate sheds light on a fragment of the postwar history of the town, which started to spread east after 1970. The economic and political situation of the time had decisive influence on architecture and urban planning, but the cosy Kuźniki estate stood out from other large-scale projects carried out in the same period thanks to the individualist approach to visual form and the harmony between the urban composition and the landscape.

Słowa kluczowe: architektura, urbanistyka, osiedle, Wrocław

Keywords: architecture, urban planning, housing estate, Wrocław

\section{Wstęp}

W 1975 r., po wizycie na wrocławskich placach budowy, reporter czasopisma „Architektura” pytał retorycznie: „Sztampa czy szukanie nowych, twórczych rozwiązań?", nawiązując do efektów pracy 
lokalnych Zakładów Wielkiej Płyty ${ }^{1}$. Lata 70 . były we Wrocławiu, podobnie jak w całej Polsce, okresem wielu nowych inwestycji mieszkaniowych, na które jednak oddziaływała specyficzna sytuacja miasta wciąż odbudowywanego, dysponującego dużymi rezerwami terenu zarówno w centrum, jak i na obrzeżach. Powojenna architektura wrocławska została zdominowana przez budownictwo mieszkaniowe, a jej rozwój, jak podkreślał Edmund Małachowicz, jest nierozłącznie zwiazany z historią odbudowy miasta ${ }^{2}$. Do 1970 r. wszystkie wrocławskie osiedla (np. Gajowice, Wrocław-Południe, Wrocław-Zachód) wznoszono w obrębie obszarów uzbrojonych jeszcze przed wojna, a nowe budynki wkomponowywano w istniejąca, poniemiecka siatkę ulic. Od połowy lat 50. można zauważyć zdecydowana przewagę inwestycji mieszkaniowych nad innymi rodzajami budownictwa, co spowodowane było przede wszystkim wspólnym dla większości polskich miast niedoborem mieszkań, we Wrocławiu jednak odczuwalnym szczególnie dotkliwie, z racji zniszczenia w czasie wojny całych dzielnic mieszkaniowych na południu i zachodzie. Nie było też konieczności inwestowania środków w nowe budynki użyteczności publicznej, bo większość z nich przetrwała wojnę, wymagała jedynie remontów lub adaptacji i dlatego projekty nowoczesnych kin, teatrów i domów handlowych pozostały jedynie na papierze ${ }^{3}$.

W okresie rządów Edwarda Gierka urbaniści przewidywali, że w latach 80. stolica Dolnego Ślaska będzie liczyć 700000 mieszkańców, i to dla nich „miasto wyjdzie poza obecne tereny zainwestowania miejskiego"4, a nowe osiedla powstana na obszarach dotąd niezabudowanych. Liczba mieszkańców została nieco przeszacowana, ale koncepcję rozwoju miasta przede wszystkim w kierunku zachodnim (to tam było najwięcej rezerw terenowych), rozpoczęto wdrażać w życie na podstawie

${ }^{1}$ Wyjątkami od reguły były wieżowce przy pl. Grunwaldzkim, dla których zaprojektowano specjalne prefabrykaty, oraz osiedle Popowice, gdzie Wrocławska Wielka Płyta (WWP) została wzbogacona o nowe elementy (np. osłony balkonów); zob. Reporter „Architektury” po wizycie we Wrocławiu, „Architektura” 1975, nr 1, s. 340.

${ }^{2}$ Małachowicz omawia zestawienie osiedli od roku 1954 (pl. Kościuszki dla 4 tys. osób) do 1971 (os. Popowice dla 19 tys. i Huby dla 26 tys.), pokazując wzrost rozmiarów osiedli i liczby mieszkań; zob.: E. Małachowicz, Twórcze środowisko architektoniczne i nowa architektura Wrocławia, w: Wrocław, jego dzieje i kultura, red. Z. Świechowski, Warszawa 1978, s. 473.

${ }^{3}$ W latach 1956-1970 nie zrealizowano we Wrocławiu żadnego z projektowanych kin ani ośrodków usługowych. Jedynym znaczącym, nowym zakładem przemysłowym wzniesionym w tym okresie, był Hutmen przy ul. Grabiszyńskiej.

${ }^{4}$ Cyt. za: R. Żabiński, Rozwój urbanistyczny od 1945 roku do czasów dzisiejszych, w: Wrocław, jego dzieje i kultura, red. Z. Świechowski, Warszawa 1978, s. 459. 
kolejnych planów zagospodarowania przestrzennego już w pierwszej połowie lat 70. i realizowano jeszcze po $1989 \mathrm{r.}^{5}$

Dzisiejszy Wrocław, tak jak Warszawa czy Szczecin, jest w dużej mierze miastem powojennego modernizmu i tym samym analiza kolejnych etapów odbudowy oraz rozbudowy wyraźnie pokazuje zależności między architektura a polityczno-gospodarczymi uwarunkowaniami oraz zmianami ustrojowymi. Pierwszy, krótki etap względnej swobody artystycznej, trwał do 1948 r., a po nim nastapił okres socrealizmu (lata 1949-1955), w którym architektura była z jednej strony determinowana przez wielkie plany odbudowy, a z drugiej - przez wciąż niepewny status polskiego Wrocławia i jego ciagłe niedofinansowanie. Wraz z odwilżą 1956 r. rozpoczą się budowlany boom i kilka lat twórczego fermentu oraz spektakularnych projektów dla nowoczesnego miasta, opracowywanych przez młodych architektów ${ }^{6}$. Dekada lat 60 ., obfitująca w ciekawe, zarówno estetycznie, jak i funkcjonalnie, realizacje, kończy się schematycznymi układami osiedli, które poddano krytyce $\mathrm{w}$ kolejnym dziesięcioleciu. W latach 70 . rozpoczynają się wielkie inwestycje, które staną się środowiskiem mieszkaniowym dla niemal 100000 ludzi $^{7} \mathrm{i}$ w dużej mierze zdefiniują charakter całych dzielnic, a powolne tempo ich powstawania będzie związane z końcem prosperity ery Gierka i kryzysem gospodarczym lat $80 .^{8}$

To „betonowe dziedzictwo”, używając określenia Andrzeja Basisty $^{9}$, jest częścia materialnej spuścizny zamkniętej już epoki historycznej, jaką jest PRL, może zatem stać się przedmiotem badań, weryfikacji i oceny. We Wrocławiu proces ten już się rozpoczał́, dotyczy jednak przede wszystkim okresu między rokiem 1945 a 1970, natomiast historia architektury lat późniejszych jest wciąż mało

${ }^{5}$ Proces zagospodarowywania zachodniej części Wrocławia wciąż nie jest ukończony, rozbudowywane sa istniejace osiedla, a na obszarach rezerw terenowych planowane są kolejne przedsięwzięcia mieszkaniowe (np. wzorcowe osiedle Nowe Żerniki, którego realizacja została zainicjowana w ramach programu Europejskiej Stolicy Kultury 2016).

${ }^{6} \mathrm{~W}$ tym czasie średnia wieku w największym biurze projektowym „Miastoprojekt Wrocław” wynosiła 30 lat. Więcej o środowisku architektonicznym: Z. Prętczyński, Pamięci architektów wrocławskich, Wrocław 2010.

7 A. Lis, Struktura przestrzenna i spoteczna terenów rekreacyjnych $w$ osiedlach mieszkaniowych Wrocławia z lat 70.-80. ubiegtego stulecia, Wrocław 2011, s. 11.

${ }^{8}$ Sytuację mieszkaniową w Polsce lat 70. szczegółowo omawia Dariusz Jarosz, tam również tabelarczyne zestawienie kosztów inwestycji mieszkaniowych na przestrzeni dekady, zob. D. Jarosz, Mieszkanie się należyu... Studium z peerelowskich praktyk społecznych, Warszawa 2010, s. 99-116.

9 A. Basista, Betonowe dziedzictwo. Architektura w Polsce czasów komunizmu, Warszawa-Kraków 2001. 
znana i przez to często sprowadzana do ogólników, bazujących na błędnych informacjach ${ }^{10}$. A przecież Popowice, Nowy Dwór, Kozanów, Gądów, Gaj, Polanka, Różanka, Muchobór i - last but not least Kuźniki sa częścia miasta, które po 1945 r. musiało na nowo określić swoją tożsamość, a także odbudować i stworzyć nowe przestrzenie do życia i mieszkania.

\section{Stan badań i źródła}

Wśród opracowań dotyczących architektury Wrocławia w XX w. wciąż brakuje publikacji na temat osiedli zbudowanych po $1970 \mathrm{r}$. Dlatego też temat Kuźnik pojawia się okazjonalnie, w zbiorowych publikacjach opisujących historię miasta i jego urbanistykę. Jak dotąd najbardziej rzetelnym i rozszerzonym tekstem jest hasło w Atlasie architektury Wrocławia z 1998 r., autorstwa Agnieszki Seidel-Grzesińskiej ${ }^{11}$. Przedstawione zostały w nim okoliczności powstania osiedla, jego kompozycja i wygląd, wymieniono także wszystkich projektantów. Podobne informacje znajdują się w Leksykonie architektury Wrocławia, hasło jest jednak (z powodu narzuconych ograniczeń wydawniczych) zdecydowanie krótsze ${ }^{12}$. Również w sposób skrótowy, nawet bez podania nazwisk architektów, zaprezentowane zostały Kuźniki w Encyklopedii Wroctawia ${ }^{13}$.

Jednym z najważniejszych tekstów dotyczących powojennej architektury jest artykuł Witolda Jerzego Molickiego w jubileuszowej publikacji wrocławskiego oddziału Stowarzyszenia Architektów Polskich autor omawia cała panoramę zjawisk tego okresu, w tym też osiedla

${ }^{10}$ Intensywne badania nad powojenna architektura i urbanistyka we Wrocławiu trwaja od pierwszej połowy lat 2000, najszerzej opracowany jest okres 1956-1970. Badania naukowe (prace licencjackie, magisterskie, doktoraty) sa od kilku lat popularyzowane za sprawą wystaw, artykułów prasowych, spotkań z architektami itd. Pełen stan badań i bibliografia zob.: A. Gabiś, „Koncepcje i rzeczywistość: wrocławska architektura 1956-1970”, praca doktorska napisana pod kierunkiem prof. Agnieszki Zabłockiej-Kos w Instytucie Historii Sztuki UWr, Wrocław 2013 (niepublikowana).

11 A. Seidel-Grzesińska, Osiedle Kuźniki, rejon ul. Hermanowskiej/Koszalińskiej/ Sarbinowskiej, w: Atlas Architektury Wroctawia, red. J. Harasimowicz, t. 2, Wrocław 1998, s. 151.

12 A. Gabiś, Osiedle Kuźniki, w: Leksykon architektury Wrocławia, red. nauk. R. Eysymontt et al., Wrocław 2011, s. 496.

${ }_{13}$ M. Opacki, Kuźniki. Osiedle mieszkaniowe „Kuźniki”, w: Encyklopedia Wroctawia, red. J. Harasimowicz, Wrocław 2000, s. 442. 
na zachodzie miasta, takie jak Nowy Dwór, Gądów, Kozanów i właśnie Kuźniki ${ }^{14}$. W tej samej publikacji znajduje się artykuł urbanistki, Danieli Przyłęckiej, skrótowo przedstawiający dzieje planowania przestrzennego w latach 1945-1995, zawierający również, przy okazji planów rozbudowy, wzmianki o Kuźnikach ${ }^{15}$. Daniela Przyłęcka jest autorką wydanej w 2012 r. książki, przedstawiajacej dzieje odbudowy i rozbudowy miasta na podstawie planów zagospodarowania przestrzennego i zawierającej szersze omówienie poszczególnych dzielnic ${ }^{16}$. W rozdziale „Budownictwo wielorodzinne osiedlowe” zaprezentowane zostały osiedla realizowane po 1970 r., razem z planami i zdjęciami. Niestety, w opisie Kuźnik znalazły się błędy dotyczące zarówno datowania, jak i nazwisk projektantów. Niemniej jednak jest to jak na razie jedyna praca, w której autorka podjęła próbę analizy urbanistyki (i częściowo architektury) całego okresu PRL we Wrocławiu ${ }^{17}$.

W publikacjach socjologów i architektów, badających społeczne struktury wrocławskich osiedli i tamtejsze warunki mieszkaniowe, nacisk położony jest na skupiska o większej skali (np. Kozanów, Polanka, Szczepin), Kuźniki nie zostały w nich uwzględnione, być może właśnie jako mało reprezentatywne, bo niewielkie i kameralne osiedle ${ }^{18}$.

Również w publikacjach z lat 70. i 80. znajdziemy jedynie wzmianki lub krótkie notki dotyczące Kuźnik - trzeba jednak pamiętać, że generalnie ogólnopolskie opracowania i czasopisma dość rzadko prezentowały dolnośląskie realizacje, natomiast ostatnie, przeglądowe książki, dotyczące wrocławskiej architektury powstały pod koniec lat 70., kiedy część osiedli była jeszcze w fazie projektowej ${ }^{19}$. Zdjęcia i podstawowe informacje o Kuźnikach zamieszczone zostały w jubileuszowym

${ }^{14}$ W.J. Molicki, Polskie domy we Wrocławiu, w: Architekci Wrocławia 1945-1995. 50 lat Stowarzyszenia Architektów Polskich we Wroctawiu i na Dolnym Ślasku, wybór i oprac. materiałów J. Zasada i A. Zwierzchowski, Wrocław 1996, s. 33-44.

15 D. Przyłęcka, O planowaniu przestrzennym Wrocławia w okresie 1945-1995, w: Architekci Wroctawia..., s. 7-26.

${ }^{16}$ D. Przyłęcka, Nie od razu Wrocław odbudowano. Plany zagospodarowania przestrzennego, koncepcje oraz projekty urbanistyczne $i$ architektoniczne a ich realizacja w latach 1945-1989, Wrocław 2012, s. 200-204.

17 We Wrocławiu wciąż nie ukazała się publikacja dotycząca architektury lat 19451989, na wzór np. książki Piotra Marciniaka o Poznaniu: P. Marciniak, Doświadczenia modernizmu. Architektura i urbanistyka Poznania w czasach PRL, Poznań 2010.

18 A. Lis, dz. cyt., s. 103-170.

19 Najważniejsza z tych publikacji to: Wrocław, jego dzieje i kultura, w której znajdują się jedynie wzmianki o planowanych, nowych inwestycjach; zob. Wrocław, jego dzieje i kultura, red. Z. Świechowski, Warszawa 1978. 
wydawnictwie „Inwestprojektu” z 1989 r. ${ }^{20}$, a w najważniejszym architektonicznym czasopiśmie „Architektura” poświęcono Kuźnikom jedna stronę, w ramach prezentacji nowych, polskich osiedli ${ }^{21}$. Przegląd wrocławskich artykułów i publikacji, mających już dziś wartość źródłowa, przynosi jedynie krótkie i ogólne opisy Kuźnik - w popularnym albumie Wrocław z lotu ptaka z 1985 r. znajduje się zwięzła notka, zdjęcie z budowy i plan całego założenia, które Olgierd Czerner opisał jako „mało znane osiedle”22.

Ten stan rzeczy niewiele się zmienił do dziś, a pogłębienie tematu utrudnia brak uporządkowanych zasobów archiwalnych, dotyczacych powojennej architektury ${ }^{23}$. Dokumentacja techniczna budynków osiedla Kuźniki znajduje się w zbiorach SM „Kuźniki”, a plany szkoły - w archiwum szkoły podstawowej nr 37 przy ul. Sarbinowskiej ${ }^{24}$. Biuro „Inwestprojekt”, w którym zaprojektowano Kuźniki oraz inne osiedla (m.in. Nowy Dwór i Kozanów), zostało w 1991 r. przekształcone w spółkę z ograniczona odpowiedzialnościa; zamknięto ja ostatecznie w 2013 r. i archiwum zlikwidowano ${ }^{25}$. W Archiwum Państwowym we Wrocławiu zachowane sa akta Wojewódzkiego Związku Spółdzielni Mieszkaniowych i Centralnego Związku Spółdzielni Budownictwa Mieszkaniowego, który zlecił „Inwestprojektowi” wykonanie dokumentacji dla Kuźnik $^{26}$. Te materiały umożliwiają częściowe zrekonstruowanie sytuacji ekonomicznej ówczesnych spółdzielni mieszkaniowych i ich członków, zawieraja też sporo interesujących danych na temat przydziałów lokali, wad technicznych budynków, opóźnień w realizacji planu itd.

${ }^{20}$ Inwestprojekt Wrocław. Przeglad prac projektowych do 1988 roku, Wrocław 1989.

21 „Architektura” 1984, nr 3, s. 31.

${ }^{22}$ Cyt. za: T. Drankowski, O. Czerner, Wrocław z lotu ptaka, Wrocław 1985, s. 38.

${ }^{23}$ Po 1989 r. zbiory wrocławskich biur projektowych uległy rozproszeniu lub zniszczeniu. W Muzeum Architektury zachowowana jest przede wszystkim dokumentacja Miejskiego Biura Projektów, w Archiwum Państwowym - niekompletne archiwum „Miastoprojektu”, dużo materiałów przechowują sami architekci. Ta sytuacja powoduje, że dużo trudniej dotrzeć do informacji na temat realizacji z ostatniego półwiecza niż do dokumentów sprzed $1945 \mathrm{r}$.

${ }^{24}$ Dziękuję za pomoc i udostępnienie materiałów panu Wiesławowi Żukrowskiemu i pani Katarzynie Kijewskiej z SM „Kuźniki” oraz pani Ewie Nakoniecznej ze Szkoły Podstawowej nr 37.

${ }^{25}$ Po likwidacji spółki dokumentacja została zniszczona, zachowały się tylko akta przechowywane w spółdzielniach. Informacja pochodzi od dawnego dyrektora „Inwestprojektu", Jerzego Kruka.

${ }^{26}$ Archiwum Państwowe we Wrocławiu (dalej: APWr), akta Wojewódzkiego Związku Spółdzielni Mieszkaniowych (dalej: WZSM) oraz akta Centralnego Związku Spółdzielni Budownictwa Mieszkaniowego (dalej: CZSBM). 
Ważnym źródłem informacji są wywiady z architektami, dzięki którym udało się przybliżyć okoliczności powstania i modyfikacji projektów, ustalić najważniejsze punkty koncepcji oraz zweryfikować część danych pojawiających się w opracowaniach ${ }^{27}$. Duże znaczenie mają też niepublikowane zbiory ikonograficzne (plany, rysunki, zdjęcia), jakimi dysponuja projektanci osiedla. Rozmowy z Wacławem Hryniewiczem i Andrzejem Jurkowskim są ważna częścią bazy źródłowej tego artykułu, stały się również podstawą pierwszej prezentacji Kuźnik przed szerszą publicznością podczas wykładów w Muzeum Współczesnym Wrocław w 2014 r. ${ }^{28}$

\section{Okoliczności powstania osiedla mieszkaniowego}

Kuźniki są niewielkim osiedlem, położonym w zachodniej części Wrocławia, w dzielnicy Fabryczna, pomiędzy Gądowem a Nowym Dworem. Granice terenu wyznaczają od południa i północy tory kolejowe, a od zachodu - rzeka Ślęza i Las Kuźnicki. Pierwsze wzmianki o osadzie w tym miejscu pochodza z końca XIII w., przez kilka stuleci był to obszar rolniczy, z folwarkiem, młynem i kilkoma gospodarstwami. W XIX w. nastapiły zmiany, które wpłynęły zarówno na rozwój samej wsi, jak i na ostateczne ustalenie jej granic i charakterystycznego, trójkątnego obrysu: w latach 1868-1870 wybudowano linię kolejowa, prowadząca z Dworca Świebodzkiego do Głogowa i w roku 1874 otwarto połaczenie Wrocław-Gwizdanów, wraz z łącznicą Kuźniki-Muchobór Wielki ${ }^{29}$. Na początku XX w. powstał dworzec, a Kuźniki (niem. Schmiedefeld) zyskały status osiedla przemysłowego, z cegielnią i fabryka ${ }^{30}$. Drugim ważnym wydarzeniem było włączenie Kuźnik w administracyjne granice Wrocławia w 1928 r. Stało się to bodźcem do rozbudowy, opierającej się przede wszystkim na budownictwie jednorodzinnym - pod koniec lat 30. osiedle miało już charakter willowego przedmieścia, w którym przeważały jednopiętrowe domy ze spadzistymi

${ }^{27}$ Wywiady z architektami (Wacławem Hryniewiczem i Andrzejem Jurkowskim) przeprowadzałam osobiście w październiku i listopadzie $2014 \mathrm{r}$.

${ }_{28}$ W ramach cyklu „Miasto-osiedle-blok”, organizowanych przez Muzeum Współczesne Wrocław (kurator cyklu: A. Gabiś), odbyło się w marcu 2014 r. spotkanie z architektem Wacławem Hryniewiczem. Dyskusja dotyczyła wrocławskich osiedli, w tym przede wszystkim Kuźnik: http://muzeumwspolczesne.pl/mww/dyskusje/dyskusja-dyskusje/miasto-osiedle-blok/ (dostęp: 30 IV 2016).

${ }^{29}$ M. Wójtowicz, Wybrane stacje kolejowe we Wrocławiu, w: Wrocławskie dworce kolejowe, red. M. Zwierz, Wrocław 2006, s. 211.

${ }^{30}$ Z. Antkowiak, Stare i nowe osiedla Wrocławia, Wrocław 1973, s. 96-97. 
1. Plan Kuźnik z 1937 r., uzupełniony w roku 1941; Muzeum Architektury we Wrocławiu, oddział Archiwum Budowlane, teczka plansz 1037, sygn. 23261

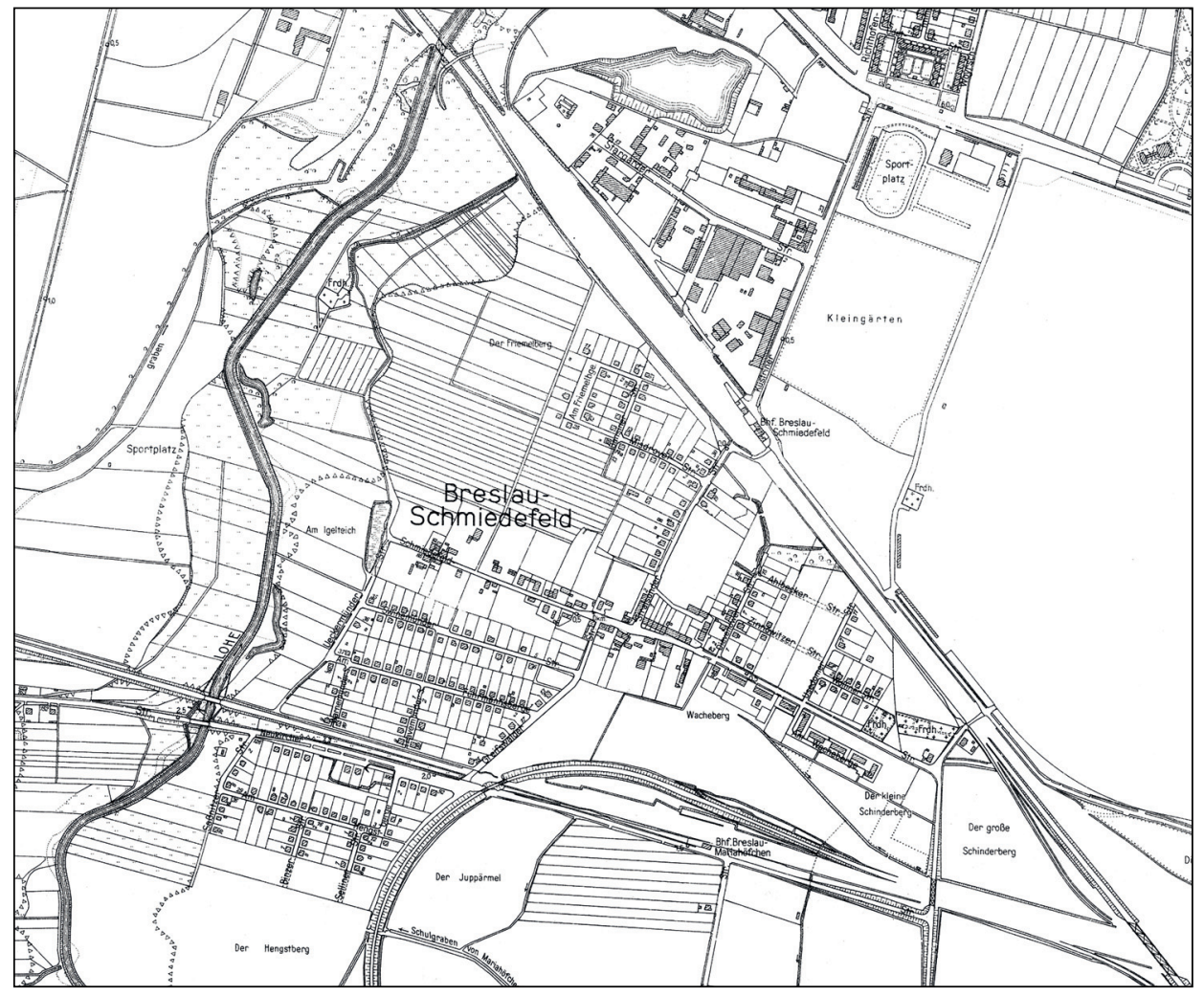

dachami, wzniesione przy nowo wytyczonych ulicach, tworzących trzy wyraźne enklawy (do 1928 r. zabudowa skupiała się jedynie przy głównej drodze, czyli obecnej Hermanowskiej) ${ }^{31}$.

Po 1945 r., kiedy Schmiedefeld zmieniło nazwę na Kuźniki, charakter osiedla nie uległ zmianie. Na początku lat 70. mieszkało tam 1375 osób, przeważała skromna zabudowa jednorodzinna, z czterema pawilonami handlowymi, kilkoma gospodarstwami ogrodniczymi i ponad trzydziestohektarową rezerwą terenu pomiędzy Hermanowską i Międzyzdrojską ${ }^{32}$.

${ }^{31}$ Zmiany, jakie zaszły w tym okresie na Kuźnikach dobrze obrazuje porównanie planów sekcyjnych z roku 1928 i 1937 . Na pierwszym zabudowa skupia się przy głównej drodze i składa się z około 50 budynków. Na drugim widoczne są nowe ulice, z domami po obu stronach (dzisiejsza Rewalska, Morska, Helska, Gołnowska, Pyrzycka, Świnoujska itd.); zob. Muzeum Architektury we Wrocławiu, oddział Archiwum Budowlane, teczka plansz 1037, sygn. 23261.

${ }^{32} \mathrm{~W} 1974 \mathrm{r}$. Antkowiak podawał, że wolne tereny przeznaczone zostały pod dalszą budowę domów jednorodzinnych; zob. Z. Antkowiak, dz. cyt., s. 97. 
Sytuacja diametralnie zmieniła się w 1973 r., kiedy Prezydium Rady Narodowej m. Wrocławia zatwierdziło „Miejscowy plan ogólny zagospodarowania Wrocławia”, bazujaccy na wytycznych zawartych w „Podstawowych kierunkach rozwoju m. Wrocławia do roku 1985”, opracowanych w Pracowni Urbanistycznej przez zespół Kazimierza Bieńkowskiego w 1969 r..$^{33}$ Jednym z najważniejszych założeń planu było wytworzenie w zachodniej części miasta dzielnic mieszkaniowych dla 150000 mieszkańców. Lokalizacja ta nie była przypadkowa: po pierwsze, były to tereny słabo zurbanizowane, dające możliwości działań na szeroka skalę, a po drugie, to właśnie na zachodzie Wrocławia skupione zostały najważniejsze i największe zakłady przemysłowe, których pracownicy potrzebowali mieszkań. W planie z 1973 r. zaznaczono obszary Nowego Dworu, Gądowa i Kozanowa jako tereny przeznaczone pod mieszkalnictwo z zabudową nowa, wysoka, jedynie Kuźniki miały uzyskać zabudowę niska ${ }^{34}$. Ten zalążek układu pasmowego planowano skomunikować szybkim tramwajem lub koleją miejska, a ośrodek usługowy dla całego rejonu umiejscowiony został na Gądowie, w rejonie ul. Na Ostatnim Groszu ${ }^{35}$.

Uzgodnienia planu, wytyczajace kierunek rozwoju Wrocławia na następną dekadę, zbiegły się ze zmianami na szczeblu centralnym, mającymi poprawić sytuację mieszkaniową w kraju, przyspieszyć rozwój miast, ale również skorygować obowiązujące dotychczas restrykcyjne normatywy, które doprowadziły do powstawania monotonnych, schematycznych osiedli, składających się z 5- i 11-kondygnacyjnych bloków, w których M2 mogło mieć 24-30 m², a M6 59-65 m². Wprowadzony w 1974 r. nowy normatyw zwiększał zarówno powierzchnie mieszkan, jak i program użytkowy w osiedlu oraz ilość terenów zielonych ${ }^{36}$. Zakładano, że M2 będzie mieć $30-35 \mathrm{~m}^{2}, \mathrm{M} 6-75-85 \mathrm{~m}^{2}$, a lokale M7 moga mieć powierzchnię nienormowaną. W ramach każdego osiedla tereny zielone miały zajmować $50 \%$ powierzchni netto, w tym musiały być uwzględnione tereny zabaw dla dzieci oraz przestrzenie rekreacyjno-sportowe, które w sumie dawały minimum 25-30 $\mathrm{m}^{2}$ terenów zielonych i rekreacji na jednego mieszkańca ${ }^{37}$. Zmiana normatywów była

${ }^{33}$ Więcej o tym planie, uchwalonym w czerwcu 1973 r., zob. D. Przyłęcka, O planowaniuu..., s. 12-13.

${ }^{34}$ Zob. taż, Nie od razuu..., s. 186.

35 Rozbudowa Gądowa była możliwa dzięki decyzji o likwidacji poniemieckiego lotniska; zob. tamże, s. 34 .

36 Więcej o normatywach z 1974 r. zob. W. Korzeniewski, Normatyw urbanistyczny i mieszkaniowy - 1974, Warszawa 1980.

${ }_{37}$ G. Dąbrowska-Milewska, Standardy urbanistyczne dla terenów mieszkaniowych - wybrane zagadnienia, „Architekturae et Artibus”, 2010, nr 1, s. 21. 
częścią szerzej zakrojonego projektu rządowego - w 1974 r. powołano uchwałą Rady Ministrów program badawczo-rozwojowy kraju, którego piąty punkt brzmiał: „Kompleksowy rozwój budownictwa mieszkaniowego". Stąd nazwa PR-5, w ramach którego miały być prowadzone naukowe, interdyscyplinarne badania do programowania i planowania rozwoju mieszkalnictwa w PRL, mające wesprzeć budowę mieszkań do $1991 \mathrm{r}{ }^{38}$ Zdecydowano również o realizacji wzorcowych osiedli, już na bazie nowych ustaleń i normatywów - te nowe wytyczne rzutowały nie tylko na kształt flagowych osiedli (w Zamościu, Krakowie, Tychach i Warszawie), ale też na większość nowych inwestycji mieszkaniowych w całej Polsce, w tym też we Wrocławiu.

Pierwszymi przedsięwzięciami tego swoistego „nowego otwarcia”, poprzedzającymi prace nad Kuźnikami, był konkurs na osiedle Gądów-Lotnisko w 1973 r. oraz projekt Nowego Dworu, osiedla dla 20000 osób, zaplanowanego na terenie częściowo zabudowanym w latach 30. i 40. niskimi blokami wielorodzinnymi. To właśnie na potrzeby Nowego Dworu, a w perspektywie - kolejnych osiedli, powołana została w 1973 r. specjalna pracownia w Zakładzie Projektowania i Usług Inwestycyjnych „Inwestprojekt”, podlegającemu Centralnemu Związkowi Spółdzielni Budownictwa Mieszkaniowego we Wrocławiu ${ }^{39}$. Na początku pracownię tworzyło trzech architektów: Wacław Hryniewicz, Wojciech Jarząbek i Andrzej Jurkowski, a konsultacjami wspierał ich Bohdan Jezierski, zatrudniony w „Inwestprojekcie Lublin” i odpowiedzialny za „Nowe Miasto II” w Zamościu, wzorcowe osiedle programu PR- $5^{40}$. Młodzi architekci dostali od kierownictwa CZSBM wolna rękę i wsparcie ze strony dyrekcji „Inwestprojektu”: najpierw powstała koncepcja, a potem zaczęto opracowywać technologię, bazująca na ogólnopolskim, otwartym systemie Wk-70 i umożliwiająca stosowanie

${ }^{38}$ Temat PR-5 wciąż czeka na opracowanie. Krótkie informacje o programie pojawiały się w prasie architektonicznej, zob. P. Zaremba, Rola architektury i urbanistyki w rozwoju budownictwa mieszkaniowego w Polsce, „Architektura” 1976, nr 10, s. 34-35; E. Kuminek, Problemy programowania i projektowania, „Architektura” 1983, nr 2, s. 18-19.

${ }^{39}$ W 1981 r. Centralny Związek Spółdzielni Budownictwa Mieszkaniowego w Warszawie powołał do życia Wojewódzki Związek Spółdzielni Mieszkaniowych we Wrocławiu, który zastapił likwidowany oddział CZSBM we Wrocławiu i Wojewódzka Spółdzielnię Mieszkaniowa. Nowy związek przejął również Zakład Projektowania i Usług Inwestycyjnych „Inwestprojekt”; zob. APWr, WZSM, sygn 2, Protokół nr 1/84 z posiedzenia Prezydium Rady Wojewódzkiej we Wrocławiu, k. 1-4.

${ }^{40}$ „Nowe Miasto II” z Zamościu było jedynym ukończonym osiedlem z PR-5, wraz z infrastruktura, usługami i zielenia; zob. P. Szafer, Nowa architektura polska. Diariusz lat 1976-1980, Warszawa 1981, s. 34-35. 
nowych elementów ${ }^{41}$. Na etapie konstrukcji i projektów technicznych do zespołu dołączył Jan Matkowski, który kontrolował formy, wylewane (często wadliwie) w fabryce domów przy ul. Szczecińskiej. Założenia dla obszaru, na którym „Miejscowy plan zagospodarowania” przewidywał wysoką zabudowę, były interesujące: wciagnięcie w strukturę osiedla istniejącej, przedwojennej tkanki, zróżnicowanie wysokości bloków, uskoki w elewacjach, operowanie segmentami przesuniętymi względem siebie (zamiast jednej, długiej bryły), koncentracja usług w centrum osiedla, sklepy w parterach domów i podział na pięć jednostek szkolnych, czego efektem miało być pięć kameralnych szkół. Na obrzeżach zaplanowano parkingi wielopoziomowe, a przy ulicy Gubińskiej - miejsce na kościół (na planach nazwane enigmatycznie „miejscem kultu" ${ }^{42}$. Budowa Nowego Dworu ruszyła w 1975 r., większość bloków ukończona została do 1980 r., ale tak naprawdę do dziś jest to osiedle niekompletne. Początkowy entuzjazm i swobodę projektową (która charakteryzowała większość spółdzielczych inwestycji) zastapiła konieczność oszczędności i doraźne rozwiązania. Planowane usługi w parterach zastapiono dodatkowymi mieszkaniami, zamiast kilku mniejszych szkół zbudowano jedna, bardzo duża, nie powstały parkingi ani centrum handlowe, mała architektura również nie doczekała się realizacji. Duża skala budynków spowodowała, że kompozycja przestrzenna stała się nieczytelna - wspólnym mianownikiem (i najciekawszym elementem dekoracyjnym Nowego Dworu, dziś już nieistniejącym), była jego kolorystyka, czyli pasy czerwieni, oranżu i żółci na wszystkich budynkach, tworzace wspólną wizualną klamrę całego osiedla ${ }^{43}$.

Eksperyment, jakim była budowa pierwszego dużego osiedla na zachodzie miasta nie powiódł się przede wszystkim z dwóch powodów: prace rozpoczęto $\mathrm{w}$ okresie boomu gospodarczego, po którym nastapiło załamanie, co wymusiło maksymalne oszczędności i rezygnację z planowanego (zbyt optymistycznie) programu usług. Drugi powód był wynikiem zapisów w „Miejscowym planie zagospodarowania przestrzennego", który narzucił architektom i inwestorowi dużą intensywność

${ }^{41}$ W-70 i Wk-70 były wielkopłytowaymi systemami elastyczniejszymi od Wrocławskiej Wielkiej Płyty (WWP). Więcej o technologicznych ograniczeniach w ówczesnym budownictwie zob. P. Marciniak, dz. cyt., s. 32-34.

${ }^{42}$ Była to jedyna możliwość zachowania rezerwy pod kościół, na którego budowę władze nie chciały wydać zgody. Większość informacji o pracach nad Nowym Dworem, planach i problemach związanych z realizacją uzyskałam podczas wywiadów z Wacławem Hryniewiczem i Andrzejem Jurkowskim.

${ }^{43}$ Oryginalna kolorystyka została obecnie zastapiona różnymi kolorami, każdy budynek ma inną barwę, co dodatkowo pogłębia chaos przestrzenny tego osiedla. 
i konieczność wprowadzenia wysokiej zabudowy. Zastosowane stopniowanie wysokości nie osłabiło, w sposób wystarczający, oddziaływania architektury o skali nieprzyjaznej użytkownikowi. Należy jednak pamiętać, że to na Nowym Dworze przełamano po raz pierwszy monopol długich, powtarzalnych boków z Wrocławskiej Wielkiej Płyty, próbując zróżnicować bryły i plany mieszkań oraz wprowadzając skromny detal (było to możliwe dzięki nowemu, bardziej elastycznemu systemowi Wk-70).

Dla młodych projektantów to zlecenie było ważnym doświadczeniem i swoistym poligonem doświadczalnym, już w trakcie realizacji zdawali sobie sprawę z niedociagnięć i problemów, jakie generuje taka zabudowa. Swoje zweryfikowane pomysły mogli wykorzystać przy kolejnym projekcie - w 1977 r. Wacław Hryniewicz przygotował koncepcję dla osiedla mieszkaniowego Kuźniki, na bazie której opracowano szczegółową dokumentację dla budynków mieszkalnych oraz szkoły. Punkt wyjścia był optymalny - klin między torami a rzeka, sasiedztwo domów jednorodzinnych, dużo terenów zielonych, a przede wszystkim zapis w planie zagospodarowania przestrzennego, że na tym obszarze należy realizować niską zabudowę ${ }^{44}$. Zespół „Inwestprojektu” w składzie: Andrzej Jurkowski (kierownik pracowni), Elżbieta i Leopold Chyczewscy oraz Andrzej Lech zaprojektował na ok. 36 ha osiedle dla 4300 osób, z 40 budynkami mieszkalnymi, dwoma pawilonami, szkoła, przedszkolem i centrum handlowo-usługowym ${ }^{45}$. Inwestorem był CZSBM i SM „Piast”, a wykonawca - Wrocławskie Przedsiębiorstwo Budownictwa Ogólnego (WPBO); prace ziemne rozpoczęto w 1978 r. i pierwsze budynki odebrano już pod koniec roku 1980. Budowa była etapowana, najpierw wznoszono bloki przy Hermanowskiej i Majakowskiego, a ostatnie przy Sarbinowskiej i Dźwirzyńskiej, ukończone w 1985 r. ${ }^{46}$

W projekcie pojawiło się kilka nietypowych rozwiązań - w przyziemiach zaplanowano mieszkania (ponad $60 \mathrm{~m}^{2}$ ), z dostępem do własnego ogródka, dla rodzin wielodzietnych lub osób niepełnosprawnych ${ }^{47}$.

${ }^{44}$ Nowe osiedle na Kuźnikach miało dopełnić istniejącą zabudowę tak, aby powstała pełna jednostka strukturalna, dzięki czemu było możliwe wyposażenie osiedla w pełen program usług podstawowych; zob. D. Przyłęcka, Nie od razuu..., s. 200.

${ }^{45} \mathrm{~W}$ późniejszym etapie prac brała udział również Barbara Kupczyk. Daniela Przyłęcka błędnie podaje nazwiska projektantów (Hyczewscy), a zamiast Andrzeja Lecha wymienia Edwarda Lacha; zob. tamże.

46 Jako ostatni odebrano blok przy ul. Sarbinowskiej 15-21, w 1987 r. Dane dotyczące poszczególnych budynków, dat ich odbioru, powierzchni i planów pochodza z archiwum SM „Kuźniki”.

${ }^{47}$ Miały to być lokale nieoddzielone progiem ani schodami od chodnika, niestety, wykonawca nie poradził sobie z tym zadaniem. 
2. Plany osiedla mieszkaniowego Kuźniki: wersja wstępna i wersja końcowa; ze zbiorów Wacława Hryniewicza

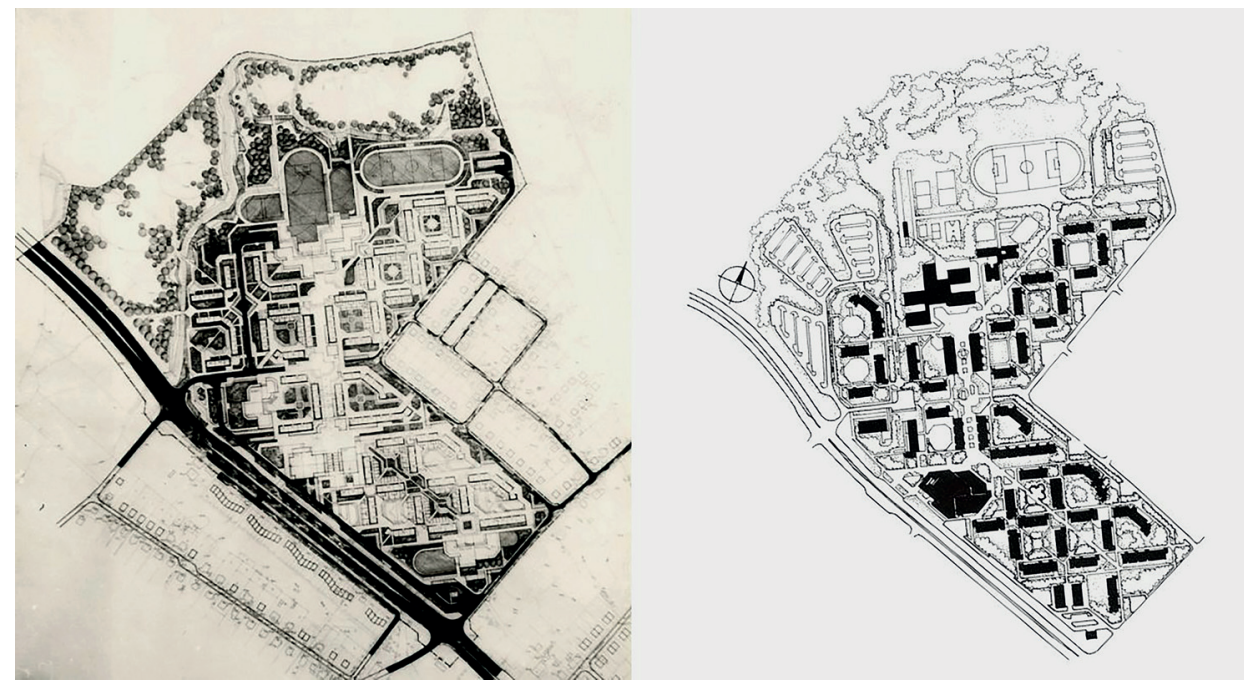

W parterach ulokowano też harcówkę, klub osiedlowy, komórki lokatorskie, a przy Sarbinowskiej kilka sklepów, dzięki czemu powstał tam mały pasaż handlowy. Plan zakładał garaże w większości budynków, ostatecznie zlokalizowano je w siedmiu blokach, natomiast duże parkingi wytyczono na skaju osiedla ${ }^{48}$. Niemal wszystkie założenia udało się zrealizować - nie powstało jedynie centrum handlowo-usługowe (obecnie jest to rezerwa terenowa), jednak jego brak, $\mathrm{z}$ racji usług ulokowanych $\mathrm{w}$ parterach bloków i dwóch wolno stojących pawilonów, okazał się zdecydowanie mniej uciążliwy niż na Nowym Dworze. Szkoła, która w koncepcji Hryniewicza była budynkiem opartym na indywidualnych rozwiązaniach i wzbogaconym o stadion, ostatecznie została zaprojektowana przez Andrzeja Jurkowskiego oraz Elżbietę i Leopolda Chyczewskich (w 1981 r.) i zrealizowana na bazie Systemu Projektowania Segmentowego Budownictwa Oświaty, w technologii wielkoblokowej (WBL) ${ }^{49}$. Jej budowa trwała

${ }^{48}$ Architektom zależało na jak największej liczbie garaży wbudowanych, aby nie powtórzyć błędu z Nowego Dworu, gdzie zaplanowane wielopoziomowe parkingi nigdy nie powstały.

${ }^{49}$ Naukę rozpoczęło około 1800 dzieci. W 1987 r. budynek nie był jeszcze w całości ukończony, prace sfinalizowano dopiero rok później. Kompletna dokumentacja szkoły oraz dzienniki budowy znajduja się w archiwum Szkoły Podstawowej nr 37 przy ul. Sarbinowskiej. Za udostępnienie tej dokumentacji dziękuję Pani Ewie Nakoniecznej. 
z przerwami od 1983 r., a pierwszy rok szkolny rozpoczął się 1 września 1987 r. $^{50}$

Dla całych Kuźnik wybrano technologię wielkoblokową (WBL), bazujaca na mniejszych elementach (blokach) i w tym przypadku było to istotne, ponieważ budynki mają układ kaskadowy (od 3 do 5 kondygnacji), uskoki i loggie, a także inne rozkłady mieszkań na każdym piętrze. WPBO nie miało doświadczenia $\mathrm{w}$ takich realizacjach, na porządku dziennym były więc wady wykonawcze, niedoróbki i opóźnienia. Szczególne kłopoty sprawiała izolacja loggii i tarasów oraz mieszkania w przyziemiach. W dokumentacji technicznej pojawiły się uwagi tego typu: „Prace przy odwadnianiu tarasów należa do najbardziej skomplikowanych. Wymagaja dużej dokładności i staranności. W przeciwnym razie taras staje się źródłem nieustannych kłopotów" ${ }^{51}$. Kłopoty mieli więc lokatorzy, nad których mieszkaniami znajdowały się tarasy - do zarządu SM „Piast” napływały skargi na zalane sufity i zacieki, powstające podczas opadów deszczu ${ }^{52}$. Mieszkania $\mathrm{w}$ przyziemiach również były zalewane, panowała w nich wilgoć, przez co mieszkańcy nie chcieli ich zajmować i sugerowali, że powinny zostać przekształcone w lokale użytkowe. W aktach CZSBM zachowała się korespondencja między lokatorami z ul. Hermanowskiej, WPBO, SM „Piast” i „Inwestprojektem” dotycząca lokalu na niskim parterze, jednego z tych przeznaczonych dla rodzin wielodzietnych i osób niepełnosprawnych. W 1981 r. spółdzielnia zarządzała dziewięcioma takimi lokalami (z 20 planowanych) ${ }^{53}$. W obliczu poważnych zarzutów (stojąca woda, problemy z ogrzewaniem, obecność szczurów) spółdzielnia zasugerowała zmianę funkcji tych mieszkań, natomiast „Inwestprojekt” bronił się, używając następujących argumentów: „odnosimy wrażenie, że negatywny stosunek odbiorców do mieszkań w przyziemiu wynika z braku zagospodarowania terenów przyległych. Jesteśmy $\mathrm{w}$ pełni przekonani, że po realizacji projektu w całości stosunek przyszłych lokatorów do tych mieszkań zmieni się

${ }^{50}$ Do kuźnickiej szkoły chodzili również uczniowie z sąsiedniego Gądowa, na którym wciąż brakowało dużej szkoły (informacja uzyskana od absolwentów szkoły przy ul. Sarbinowskiej).

${ }^{51}$ Cytat z dokumentacji budynku przy ul. Sarbinowskiej 15-21.

${ }^{52}$ Te skargi rozpatrywał inspektorat lustracji CZSBM. Zob. APWr, CZSBM, sygn. 308, k. 119, Korespondencja między Teresą Kalisz a Spółdzielnią Mieszkaniową „Piast”.

${ }^{53} \mathrm{~W}$ korespondencji to samo mieszkanie jest nazywane zupełnie inaczej - w emocjonalnym liście Zbigniewa Laszka jest mowa o „suterynie”, a w odpowiedziach na jego list pojawia się „przyziemie”; zob. APWr, CZSBM, sygn. 306, List Zbigniewa Laszka do Najwyższej Izby Kontroli we Wrocławiu, k. 36-39. 
radykalnie" ${ }^{54}$. Specjalnie powołana komisja stwierdziła szereg wad konstrukcyjnych i wykonawczych, zatkane studnie deszczowe i drenażowe oraz konieczność odwodnienia mieszkań i przylegajacych do nich ogródków, także w budynkach jeszcze niezasiedlonych - wszystkie poprawki zlecono $\mathrm{WPBO}^{55}$.

Problemy z niskim poziomem wykonawstwa na Kuźnikach nie były oczywiście czymś wyjątkowym, większość ówczesnych inwestycji borykała się niedoborami materiałowymi, niedociagnięciami i koniecznościa poprawek - nie miały ich jedynie tak prestiżowe przedsięwzięcia jak np. centrum diagnostyki „Dolmed”, otwierane przez Gierka w 1977 r. W pewnej mierze sytuacja na placach budowy wynikała również z samego systemu realizacji i przydziału mieszkań, uwikłanego w biurokratyczną strukturę dużych spółdzielni, zależnych od rad narodowych i zakładów pracy. Już w połowie lat 60 . zaczęto ograniczać aktywność mniejszych, niezależnych spółdzielni i łączyć je w większe struktury (tzw. akcja łączeniowa) ${ }^{56}$. Swoisty monopol spółdzielni, które zarządzały wielkimi placami budowy, prowadził do obniżenia jakości wykonawstwa, a czas oczekiwania na mieszkania zaczął się wydłużać: w latach 1961-1965 było to kilka lat, a w kolejnej dekadzie - nawet kilkanaście ${ }^{57}$. W 1984 r. SM „Piast” zarządzała czterema osiedlami (w tym Kuźnikami), z zasobem 363 tys. $\mathrm{m}^{2}$, a koszty metra kwadratowego wahały się od 4700 do 5000 złotych (takie były ceny na ukończonym wtedy osiedlu Gądów Mały) ${ }^{58}$. W zachowanych protokołach lustracyjnych SM „Piast” znaleźć można szereg pism dotyczących przyspieszenia przydziału mieszkania z powodu trudnych warunków bytowych i bardzo długiego czasu oczekiwania ${ }^{59}$, a także odwołań od ostatecznego

${ }^{54}$ Cyt. za: APWr, CZSBM, sygn. 306, Protokół lustracji specjalnej Spółdzielni Mieszkaniowej „Piast”, k. 40.

${ }^{55}$ Cała korespondencja zob. APWr, CZSBM, sygn. 306, Korespondencja między Spółdzielnią Mieszkaniową „Piast” a Centralnym Związkiem Spółdzielni Budownictwa Mieszkaniowego, k. 42-47.

${ }^{56}$ Brakuje całościowej monografii polskiej spółdzielczości. Najważniejszym opracowaniem jest książka Krzysztofa Madeja o spółdzielczości w latach 60.; zob. K. Madej, Spółdzielczość mieszkaniowa. Władze PRL wobec niezależnej inicjatywy społecznej (1961-1965), Warszawa 2003.

${ }^{57}$ K. Madej, dz. cyt., s. 131. Więcej o spółdzielczości w latach 1970-1989 zob. D. Jarosz, dz. cyt., s. 257-274.

58 APWr, CZSBM, sygn. 307, Rozliczenie wstępne kosztów mieszkania, k. 67-68.

${ }_{59}$ Np. jeden z członków spółdzielni czekał na przydział od 1973 r. i w 1982 r. postanowił przyspieszyć proces przenosin z mieszkania 35-metrowego (w którym mieszkał z żona, dzieckiem oraz teściami) do nowego mieszkania i złożył skargę do spółdzielni, przy okazji zwracając uwagę na nieprawidłowości w przyznawaniu lokali osobom, którym się one nie należą; APWr, CZSBM, sygn. 306, Korespondencja między Czesławem 
kosztu lokalu, który okazał się być wyższy niż pierwotnie zakładano ${ }^{60}$. Wrocławskie spółdzielnie musiały też realizować tzw. skierowania ${ }^{61}$, m.in. dla Wydziału Spraw Lokalowych, dla Ślaskiego Okręgu Wojskowego, Komendy Wojewódzkiej MO, WKS Śląsk, a także dla absolwentów z wyróżnieniem i Biura Handlu Zagranicznego (BHZ) „Locum”, które za dewizy doposażało lokale np. w glazurę, a także pośredniczyło w sprzedaży mieszkań ${ }^{62}$. Na przykład w 1982 r. SM „Piast” przeznaczyła na Kuźnikach trzy budynki dla Wydziału Spraw Lokalowych, na osiedlu Kosmonautów - 231 mieszkań dla Śląskiego Okręgu Wojskowego $^{63}$. Tym samym skład społeczny osiedli był dość zróżnicowany, obok wieloletnich członków spółdzielni i robotników (np. z zakładu Hydral) mieszkali wojskowi, milicjanci lub zasłużeni sportowcy ${ }^{64}$.

Gdy osiedle mieszkaniowe i szkoła były już właściwie ukończone, wyraźnie zaczą być odczuwalny brak kościoła. Kuźniki w latach 50 . podlegały parafii w Muchoborze Wielkim, a w 1962 r. powstała nowa, wspólna parafia z Żernikami, gdzie znajdował się kościół. W maju 1988 r. odprawiono pierwszą mszę pod krzyżem ustawionym na placu przy ulicy Koszalińskiej, i w tym samym roku została wzniesiona nielegalna kaplica, w której zaczęto odprawiać nabożeństwa. Władze nie chciały się zgodzić na budowę kościoła, zezwoliły natomiast na wybudowanie domu katechetycznego, który był niezbędny z racji dużej szkoły, już działającej na Kuźnikach. Architekt Andrzej Łukaszewicz zaprojektował dom katechetyczny w taki sposób, żeby we wnętrzu znalazły

Żołędziowskim a Inspektoratem Lustracji Centralnego Związku Budownictwa Mieszkaniowego, k. 50-59.

${ }^{60}$ Te dokumenty są też interesującym świadectwem życia codziennego, obrazują bowiem warunki, w jakich na początku lat 80 . XX w. mieszkali wrocławianie (bez sanitariatów, bez ogrzewania itd.).

${ }^{61}$ System skierowań obowiązywał w większości spółdzielni mieszkaniowych i polegał na przydzielaniu mieszkań osobom, które nie były członkami spółdzielni, ale np. były zatrudnione w przedsiębiorstwach budowlanych, w administracji państwowej itd. Więcej o problemach związanych z przydziałem mieszkań, zob. D. Jarosz, dz. cyt., s. 274-295.

${ }^{62}$ APWr, WZSM, sygn. 3, Informacja na temat działalności BHZ „Locum” w układzie rzeczowym i finansowym, k. 92-93. Więcej o roli BHZ „Locum”: D. Jarosz, dz. cyt., s. $297-298$.

${ }^{63}$ APWr, WZSM, sygn. 3, Uchwała Rady Wojewódzkiego Związku Spółdzielni Mieszkaniowych we Wrocławiu, k. 58-66.

${ }^{64}$ Kuźniki też miały taki zróżnicowany skład. Brakuje dokumentów, które jednoznacznie wskazywałyby, że było to osiedle resortowe, a taka opinia panuje wśród obecnych mieszkańców. To właśnie dzięki przydziałom dla milicji, wojska i sportowców miało dojść do relatywnie szybkiego ukończenia inwestycji, wraz z większością zaplanowanej infrastruktury. Opinie te wymagają jednak potwierdzenia w źródłach. 
3. Osiedle mieszkaniowe Kuźniki w budowie, fot. Tadeusz Drankowski; ze zbiorów Zakładu Narodowego im. Ossolińskich, Dział Dokumentów Życia Społecznego, f. 2655, nr 31

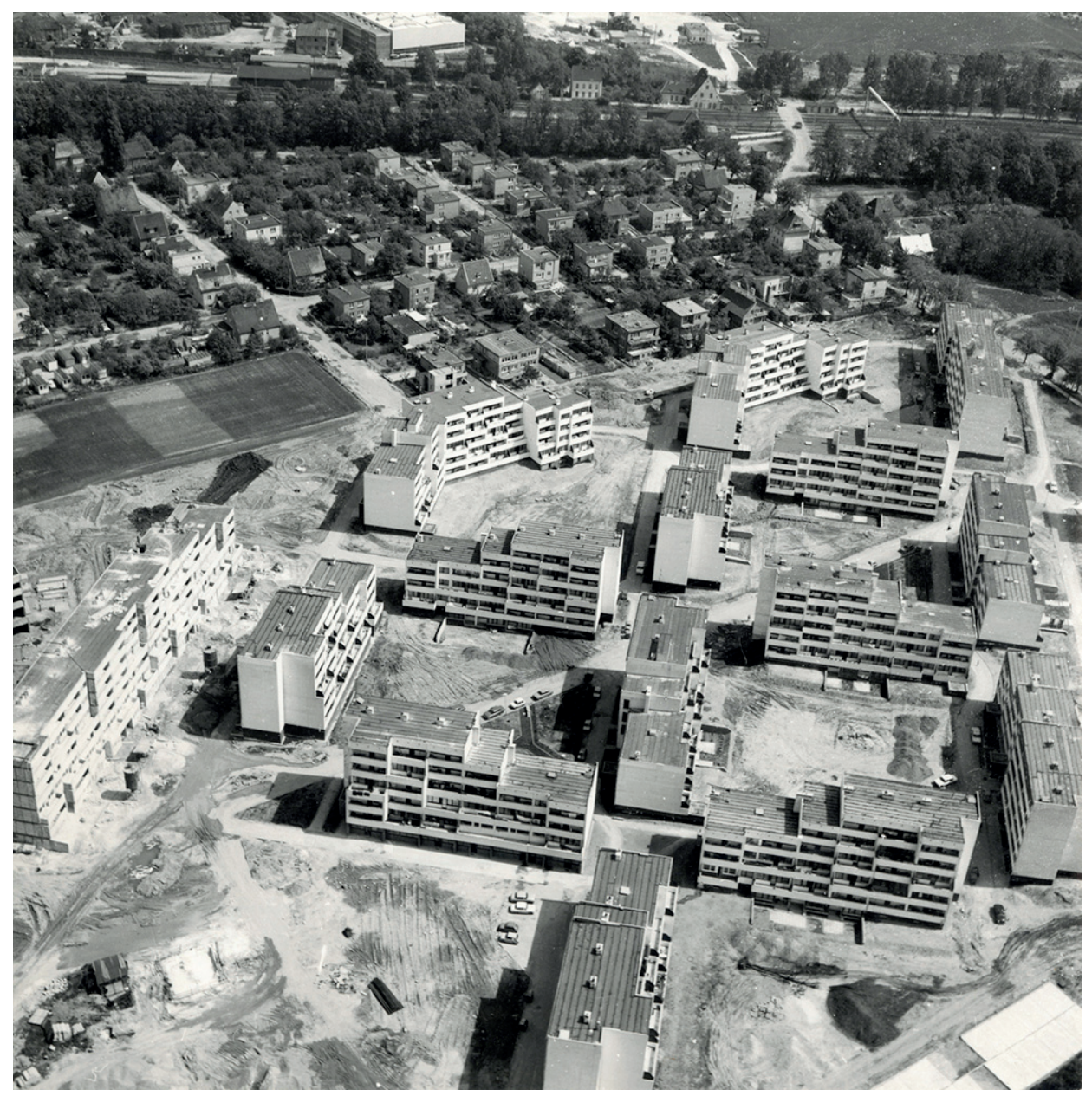

się zarówno sale do nauki, jak i miejsce na ołtarz (taka była sugestia władz kościelnych). Budynek ukończony został po przełomie $1989 \mathrm{r}$. i krótko pełnił swoja pierwotną funkcję, bo nauczanie religii przeniesiono do szkół (obecnie jest to dom parafialny i plebania) ${ }^{65}$. W $1992 \mathrm{r}$.

${ }^{65}$ Okoliczności powstania kuźnickiej kaplicy (najpierw nielegalne miejsce spotkań, a potem zgoda władz na budowę domu parafialnego) są podobne do wielu przypadków w całej Polsce w latach 80. i obrazuja skomplikowane relacje między władza państwowa a Kościołem katolickim. Więcej o samowolach budowlanych, wieloletnich negocjacjach i pozwoleniach na budowę nowych kościołów zob. R. Gryz, Pozwolić czy nie? Wtadze PRL wobec budownictwa sakralnego w latach 1971-1980, Kielce 2007, s. 124-158. 
powstała samodzielna, kuźnicka parafia pod wezwaniem św. Andrzeja Boboli, której proboszcz, ksiądz Bolesław Szczęch, przez kilka lat starał się o możliwość uzyskania działki i środków na budowę kościoła. Prace rozpoczęto w 1995 r., a konsekracja miała miejsce w roku 2000. Świątynię, która jest obecnie najwyższą dominantą osiedla, zaprojektował wrocławski architekt Piotr Furmanek ${ }^{66}$.

Po roku 1989 i likwidacji CZSBM część wielkich spółdzielni zaczęła dzielić się na mniejsze struktury. W 1997 r. ze SM „Piast” wydzielona została SM „Kuźniki”, która obecnie zarządza całym osiedlem mieszkaniowym, liczącym 2541 mieszkańców ${ }^{67}$. Zakład Projektowania i Usług Inwestycyjnych „Inwestprojekt” przekształcił się w 1990 r. w spółdzielnię osób prawnych, a rok później stał się spółką z ograniczoną odpowiedzialnościa. Spółka zawiesiła działalność w 2010 r., ostatecznie została zlikwidowana w roku 2013 i wykreślona z KRS.

Dzięki zapisom w miejscowych planach nie powstały na Kuźnikach żadne wysokie budynki - obecnie zabudowa osiedla składa się z willi, niskich bloków wielorodzinnych oraz szeregówek, i w przyszłości może być jedynie punktowo uzupełniana. Klin między torami i rzeka jest teraz niemal w całości zagospodarowany i z każdej strony otoczony zielenia.

\section{Urbanistyka i architektura osiedla mieszkaniowego Kuźniki}

Teren o powierzchni około 36 ha, który przeznaczono pod budowę osiedla, ma obrys zbliżony do litery L i jest ograniczony ulicami Hermanowską i Koszalińska. Przy opracowywaniu koncepcji urbanistycznej wytyczono nowe ulice: Sarbinowską oraz Włodzimierza Majakowskiego, natomiast istniejąca ulicę Dźwirzyńską przedłużono w kierunku północnym. Oprócz dróg dojazdowych, między blokami wytyczono też ścieżki i chodniki, pozwalające na oddzielenie ruchu kołowego od pieszego. Układ komunikacyjny jest prosty, oparty na dwóch osiach, zbiegających się pod kątem prostym: wszystkie drogi prowadzą do środka osiedla, w kierunku kwadratowego placu i dwóch ciagów sklepów - na przedłużeniu tego małego pasażu handlowego znajduje się budynek

${ }^{66}$ Dokumentacja projektowa znajduje się w posiadaniu parafii. Większość informacji na temat powstania parafii na Kuźnikach pochodzi z wywiadu z proboszczem, ks. Bolesławem Szczęchem, któremu bardzo dziękuję za tę rozmowę.

${ }^{67}$ Dane z roku 2014. 
szkoły. Ta przestrzenna klamra byłaby zapewne jeszcze bardziej czytelna, gdyby powstał planowany duży pawilon handlowo-usługowy ${ }^{68}$. Kuźniki zostały zaprojektowane na siatce kompozycyjnej założonej pod kątem 45 stopni względem istniejącego układu uliczek przedwojennych, przez co powstało wrażenie pewnej odrębności od starszej części, a także uzyskano optymalne nasłonecznienie mieszkań. 40 budynków mieszkalnych odsunięto od ulic i zgrupowano pod katem prostym wokół małych, kwadratowych wnętrz z zieleńcami i placami zabaw, dzięki czemu powstały kameralne wewnętrzne przestrzenie wspólne. Efekt prywatności i zaciszności wzmocniony został przez zaprojektowanie dla mieszkań na parterach indywidualnych ogródków, które płynnie przenikają się z ogólnodostępnymi terenami zielonymi. Zabudowa nie tworzy pierzei, krótkie i niskie budynki sa wolno stojące i nie łącza się narożnikami, jednak odległości między nimi są na tyle niewielkie i regularne, że układ całości jest zwarty i czytelny. W kompozycji osiedla widać zróżnicowanie intensywności zabudowy - w części bliższej ulicom Koszalińskiej, Hermanowskiej i Majakowskiego wnętrza blokowe sa zamknięte ze wszystkich stron, ukierunkowane dośrodkowo, co dodatkowo podkreślono spiętrzeniami wysokości budynków. Natomiast przy ul. Sarbinowskiej wnętrza częściowo otwarto, dzięki czemu możliwe jest wizualne i przestrzenne zintegrowanie z sąsiednimi terenami zielonymi, łakami i pobliskim lasem. Najbardziej skrajny blok, przy ul. Sarbinowskiej 2-8, na planie zbliżonym do litery C, otwiera się niemal całkowicie w kierunku ogródków działkowych. Sasiedni, niski i obszerny trójkondygnacyjny budynek szkoły, złożony z pięciu segmentów połączonych atrium, jest przestrzennym zwornikiem osiedla: podkreśla osiowość kompozycji, zamyka perspektywę pasażu handlowego i całego ciagu zabudowy. Za szkoła, będąca najdalej wysuniętym na zachód budynkiem osiedla, znajduje się część rekreacyjna $\mathrm{z}$ boiskami, stanowiacca naturalne przejście między terenem zabudowanym a Lasem Kuźnickim.

Osiedle nie ma wyraźnie zaakcentowanego wjazdu czy wejścia planowano zaznaczyć je poprzez zlokalizowanie centrum handlowego, wtedy podkreślony byłby wjazd w połowie ul. Hermanowskiej (ale centrum nie powstało), natomiast większy zespół pawilonów na narożniki ul. Hermanowskiej i Koszalińskiej zredukowany został do dwóch

68 Ta rezerwa terenowa (czyli duża, pusta łąka) w 2016 r. została przeznaczona pod budowę trzech nowych, pięciokondygnacyjnych budynków mieszkalnych (właścicielem jest deweloper, firma Triada Dom). Zakończenie inwestycji, która dogęści istniejąca zabudowę i wpłynie na częściową zmianę charakteru całego osiedla, przewidziano na rok 2018. 
4. Makieta osiedla mieszkaniowego Kuźniki i zdjęcia z czasu budowy; ze zbiorów Wacława Hryniewicza

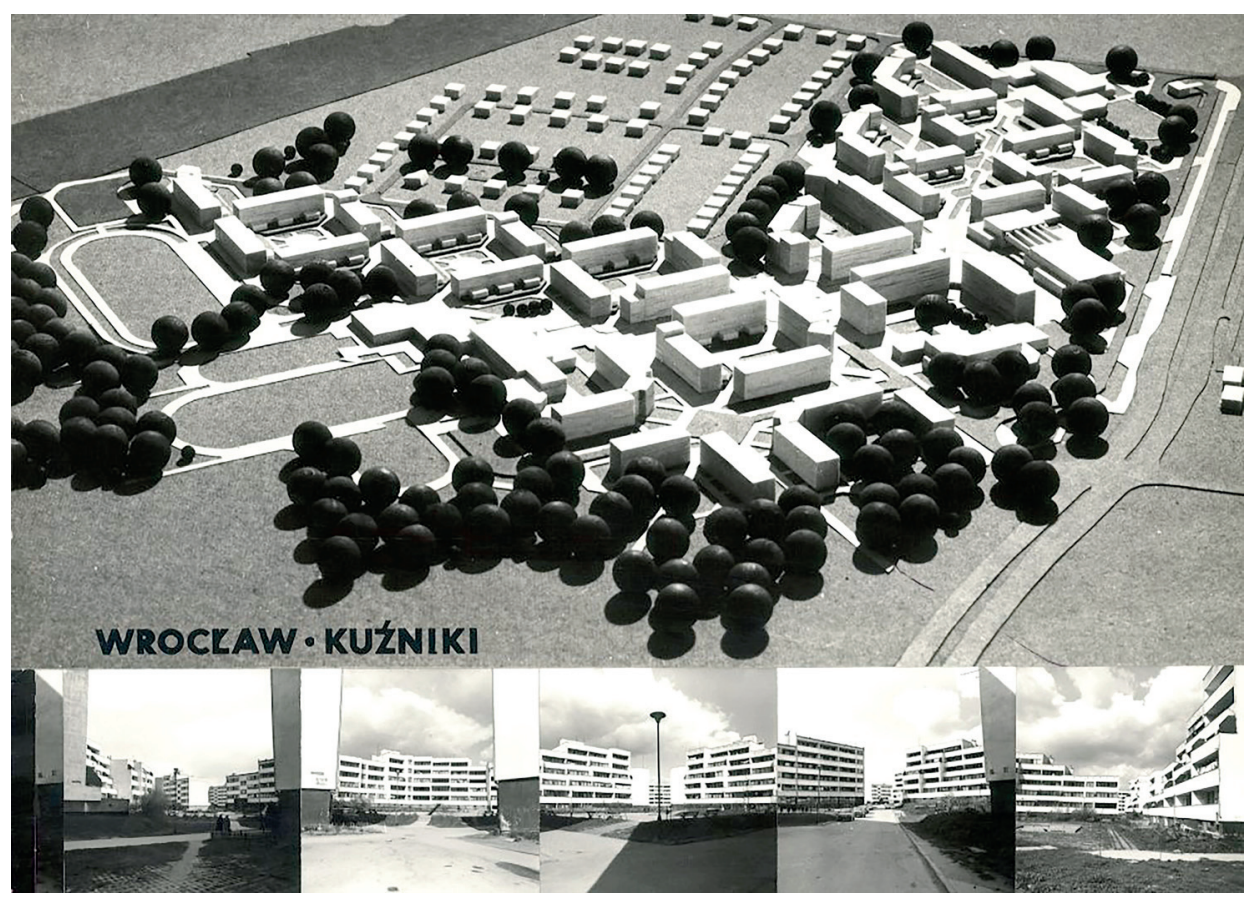

5. Plan osiedla Kuźniki; oprac. A. Gabiś

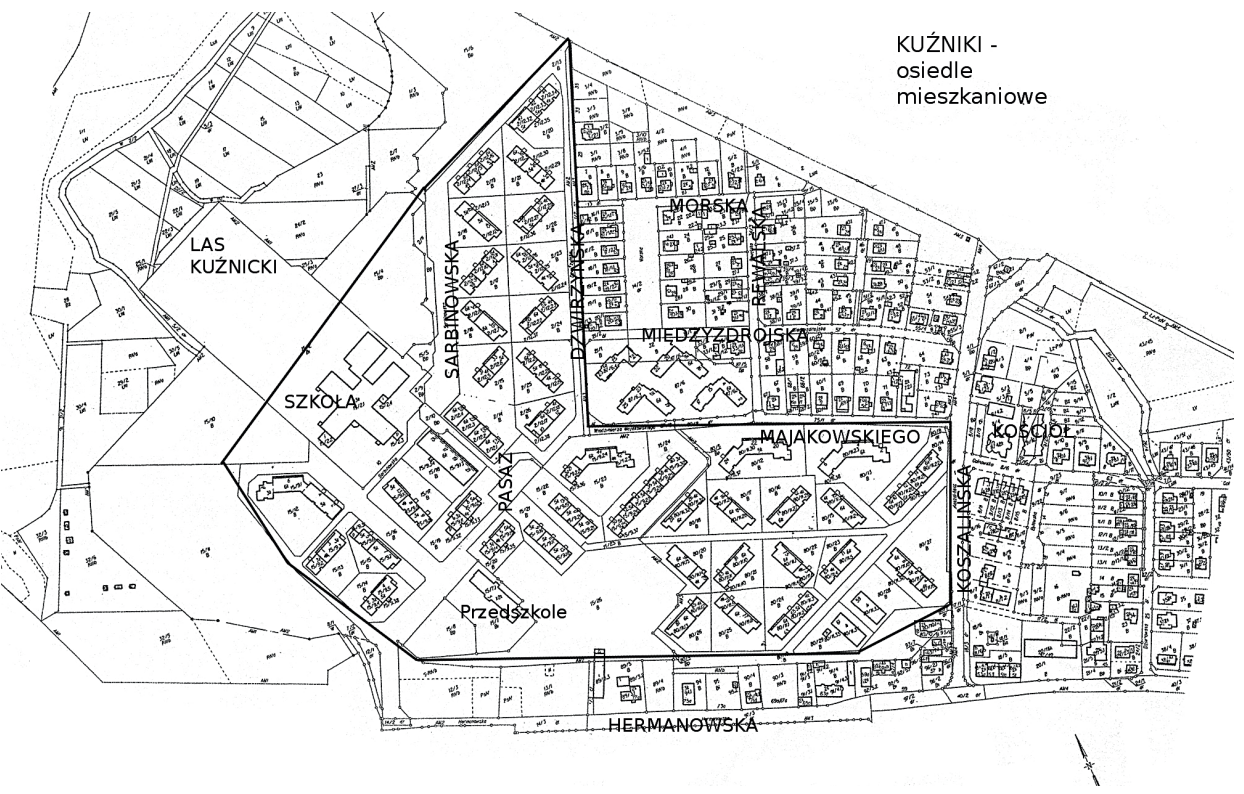


podłużnych, ustawionych równolegle do siebie, parterowych sklepów. Pas zieleni, który oddzielał te budynki i pierwsze bloki osiedla od ulicy jest obecnie zabudowany, co powoduje dezorientację i przestrzenny chaos. Do głównej idei urbanistycznej próbowano dostosować cztery nowsze bloki, wzniesione na działce pomiędzy Majakowskiego a Międzyzdrojska, czyli między osiedlem mieszkaniowym a dawną zabudowa. Udało się to jednak tylko połowicznie, przez co styk dwóch tkanek urbanistycznych w tym miejscu nie jest zbyt harmonijny. Natomiast nieplanowanym przez projektantów w latach 70. domknięciem kompozycji stała się strzelista bryła kościoła, konsekrowanego w 2000 r. Mimo że znajduje się poza obszarem osiedla, bo po drugiej stronie ulicy Koszalińskiej, to przez zlokalizowanie na przedłużeniu ul. Majakowskiego kościół jest elementem akcentujacym osiowość całego założenia i jego przestrzenna dominanta.

Budynki mieszkalne, wzniesione w technologii WBL, były projektowane indywidualnie i bazują na kilku rozwiązaniach kompozycyjnych, jednak wspólne dla wszystkich jest zróżnicowanie elewacji (poprzez zastosowanie loggii, tarasów i galerii) oraz stopniowanie wysokości, przy czym żaden blok nie ma więcej niż pięć kondygnacji. Bloki przy Hermanowskiej bazuja na kompilacji budynku klatkowego i galeriowego, w przyziemiu mają trzy lub cztery mieszkania, na kondygnacjach od pierwszej do trzeciej po sześć lokali, na czwartej - cztery, a na ostatniej - trzy. Rozplanowanie wnętrz jest więc widoczne na zewnątrz, powstały różnice w wysokości między trzecią a piątą kondygnacja, a plany mieszkań o traktach różnej głębokości (na każdej kondygnacji inne) spowodowały uskoki na elewacjach, podkreślone loggiami i tarasami, powstałymi właśnie dzięki tym przesunięciom. Ten moduł został rozbudowany o jeden segment (galeria i dwie klatki schodowe, np. ul. Hermanowska 63-67, Koszalińska 4-8) i o dwa segmenty (galeria i trzy klatki schodowe, Koszalińska 10-16). W rejonie ulicy Sarbinowskiej i Dźwirzyńskiej przeważają budynki trzyklatkowe, skromniejsze, o mniej zróżnicowanych bryłach, równej wysokości i tylko nieznacznych przesunięciach głębokości (np. Sarbinowska 39-43, Dźwirzyńska 24-28). Również prostą formę mają bloki z usługowymi parterami, pierwotnie o czterech kondygnacjach, obecnie podwyższone do pięciu (Sarbinowska 15-21, 23-29). Najdłuższym blokiem na całym osiedlu jest sześcioklatkowy budynek przy Majakowskiego 30-44, złożony z powtarzalnych segmentów i z dwustopniowym obniżeniem od strony ulicy. Natomiast jedynymi blokami, które nie zostały zaprojektowane na planie prostokata, są cztery nietypowe budynki o planie zbliżonym do litery C, również w mieszanym układzie galeriowo-klatkowym. Trzy 
z nich usytuowane są wzdłuż ulicy Majakowskiego i otwierają się na wspólny dziedziniec, do wnętrza osiedla ${ }^{69}$. W przyziemiu maja garaże, środkowa część z galeriami liczy pięć kondygnacji, a boczne skrzydła sa niższe. Czwarty budynek, przy ul. Sarbinowskiej 2-8 jest o jeden segment dłuższy, posiada dwie klatki schodowe.

W kompozycji elewacji przeważaja podziały horyzontalne, wzmocnione przez pasy pełnych balustrad loggii i galerii - efekt pewnej przysadzistości zneutralizowany został stopniowaniem wysokości oraz uskokami murów, dynamizującymi niskie bryły i tworzacymi ciekawe efekty światłocieniowe. Plastyczność budynków podkreślona została stonowana kolorystyka, wspólną dla całego osiedla, także dla szkoły: ściany pomalowane zostały na biało, a cokoły i stolarka - na ciemnobrazowo. Zdaniem architektów była to optymalna kolorystyka dla tak kameralnego założenia, w którym na pierwszym planie miała występować zieleń, zarówno ta projektowana, jak i ta już istniejąca ${ }^{70}$. Budynki uzyskały nie tylko ciekawą plastycznie formę, ale również indywidualny detal (donice, skrzynie na kwiaty, ekrany między tarasami itd.) oraz starannie zaaranżowane otoczenie i mała architekturę. Nie ograniczono się przy tym do placów zabaw, ławek przy skwerze, kwietników czy osłon na śmietniki - na terenie całego osiedla utworzone zostały wyniesienia i zagłębienia $\mathrm{w}$ gruncie, dzięki czemu powstały małe pagórki i wały ziemne, oddzielone schodkami lub murkami oporowymi. Stąd wrażenie, że teren nie jest całkiem płaski, a jedne bloki stoją niżej lub wyżej od innych. I stąd też efekt jeszcze silniejszego połączenia z pobliskimi terenami zielonymi, zachowanymi częściowo $\mathrm{w}$ stanie naturalnym.

Analizując zabudowę osiedla Kuźniki, trzeba również zwrócić uwagę na wnętrza, na metraże i rozplanowanie mieszkań. Zaprojektowano ich 1270, już według nowych normatywów, z przewaga mieszkań typu M3 i M4 (60\% wszystkich lokali), mniejszych M2 (20\%), większych M5 (15\%) i największych M6 (5\%) ${ }^{71}$. W jednym budynku połączono dwa układy komunikacyjne: klatkowy, z mieszkaniami dostępnymi z klatki schodowej, oraz galeriowy, z wejściami przez zewnętrzna galerię. Dzięki takiemu zabiegowi uzyskano ciekawszą kompozycję elewacji, ale również zaoszczędzono sporo miejsca, które zamiast na klatkę

69 Majakowskiego 2-6, 20-24, 42-44/Dźwirzyńska 21.

${ }^{70}$ Wytyczne dotyczace kolorystyki zawarte zostały w dokumentacji technicznej. Również w rozmowach architekci podkreślaja, że takie były założenie dla Kuźnik maksymalna prostota i harmonia z otoczeniem. W przeciwieństwie do Nowego Dworu, gdzie pojawiły się intensywne kolory, mające służyć indentyfikacji na dużym osiedlu.

${ }^{71}$ Zob. Przeglad osiedli mieszkaniowych, „Architektura” 1984, nr 3, s. 31. 
6. Osiedle mieszkaniowe Kuźniki w 1982 r.; fot. Romuald M. Sołdek (zdjęcie było publikowane w albumie Wrocław - czas i architektura, KAW, Wrocław 1983)

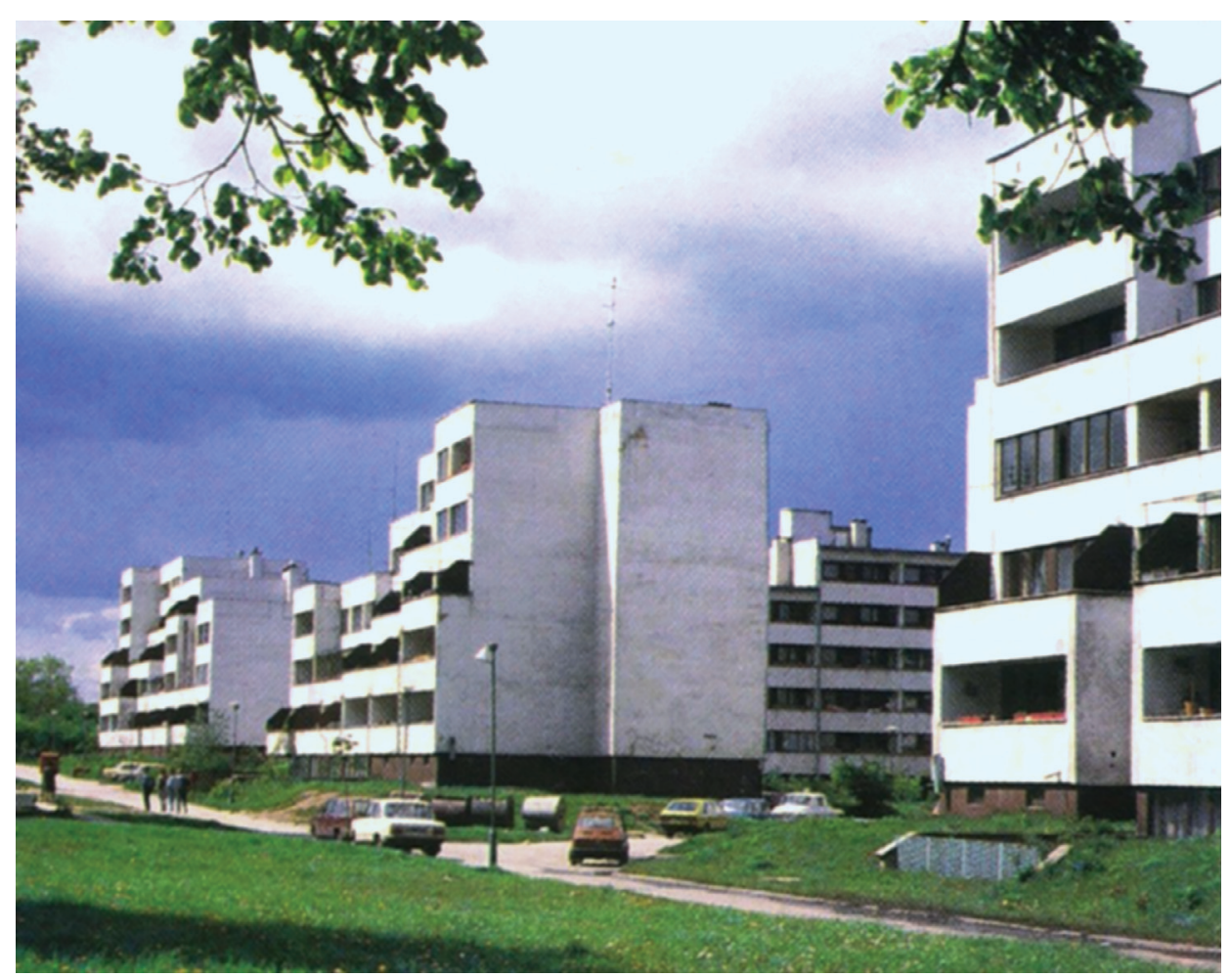

schodową mogło być wykorzystane na zwiększenie metraży. Kuchnie, galerie i wejścia znajdują się po północnej lub północno-wschodniej stronie, dzięki czemu bardziej nasłonecznione są pokoje dzienne, po drugiej stronie. Niemal wszystkie mieszkania na Kuźnikach sa jasne, dwustronne, rozkładowe, z kuchnią i łazienką po bardziej zacienionej stronie (od galerii) i pokojami po stronie słonecznej, a rozkład każdej kondygnacji różni się od kolejnej. Jedynie przy Sarbinowskiej, w czteroklatkowych blokach z usługami na parterach, zastosowano powtarzalne kondygnacje. Na piętrze sa po cztery mieszkania M2 (pow. 35,59 $\mathrm{m}^{2}$ ), jednostronne, z pośrednio doświetlonymi kuchniami ${ }^{72}$. W pozostałych budynkach metraże są większe i rozkłady bardziej funkcjonalne. Najczęściej powtarzany jest następujący układ mieszkań: w przyziemiu trzy lub cztery mieszkania M4 (pow. $63,43 \mathrm{~m}^{2}$ ) z niezależnym wejściem i własnym ogródkiem (opcjonalnie w przyziemiach znajdują się komórki

72 Zaprojektowanie takich mieszkań było koniecznościa, jeśli w budynku miały się znaleźć usługi (przez co parter nie pełnił funcji mieszkalnych). 


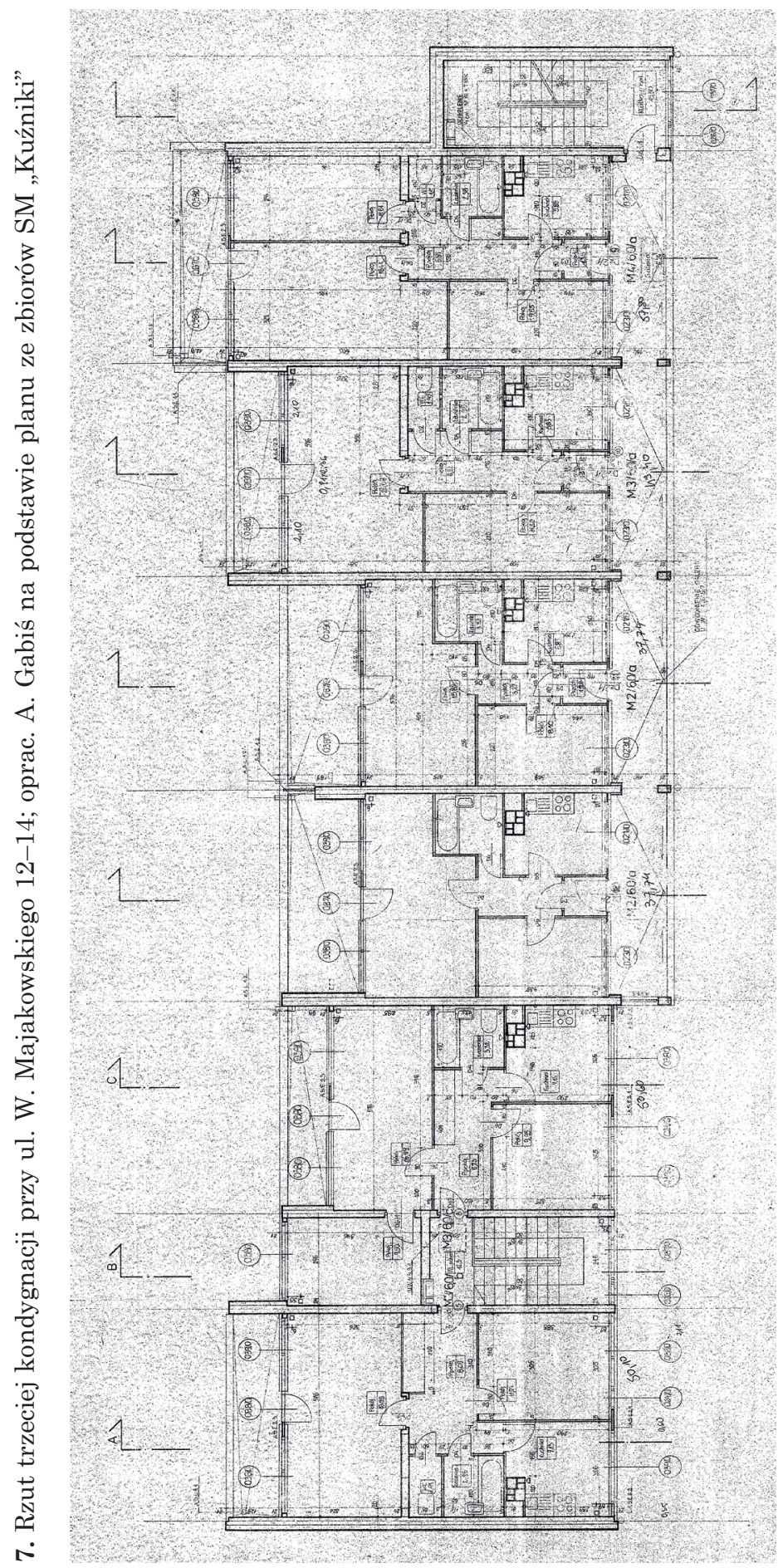


8. Rzut pierwszej i czwartej kondygnacji w budynku przy ul. W. Majakowskiego 2-6, 20-24, 42-44/Dźwirzyńska 21; oprac. A. Gabiś, za: „Architektura”, nr 3, 1984, s. 31
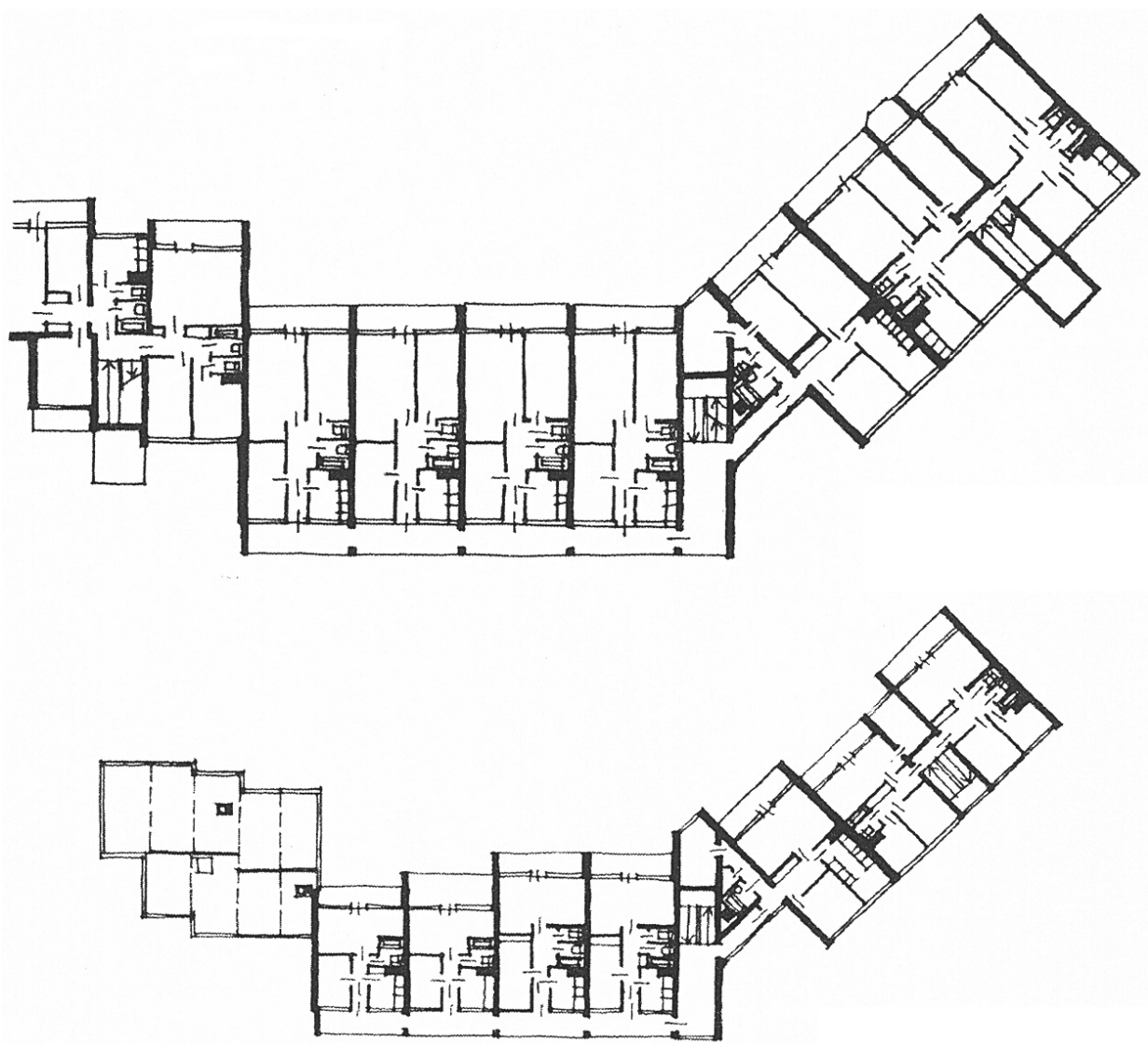

lokatorskie albo garaże). Na pierwszej kondygnacji sześć mieszkań, dwa (M5 o pow. 71,68 $\mathrm{m}^{2}$ i M4 o pow. $58,55 \mathrm{~m}^{2}$ ) dostępne przez klatkę schodowa, cztery - z galerii (M4 o pow. $57,82 \mathrm{~m}^{2}$ ). Na drugiej kondygnacji metraże są już nieco mniejsze: mieszkania z klatką schodowa to M4 $\left(59,58 \mathrm{~m}^{2}\right)$ i M3 $\left(50,14 \mathrm{~m}^{2}\right)$, a z galeriami - M3 $\left(49,39 \mathrm{~m}^{2}\right)$ i trzy M4 $\left(57,82 \mathrm{~m}^{2}\right)$. Na trzeciej kondygnacji mieszkania maja już zdecydowanie różne głębokości i tym samym różne metraże: z klatki dostępne sa dwa M3 (50,14 $\mathrm{m}^{2}$ i 53,56 $\left.\mathrm{m}^{2}\right)$, a z galerii jedno M4 (57,82 $\left.\mathrm{m}^{2}\right)$, dwa M3 $\left(49,39 \mathrm{~m}^{2}\right)$ i jedno M2 $\left(38,17 \mathrm{~m}^{2}\right)$. Od czwartej kondygnacji mieszkania znajdują się już tylko w czesści z galeria, nad częścią z klatka schodowa jest dach: na czwartej kondygnacji są cztery lokale (dwa M3 i dwa M2, o powierzchni jak te piętro niżej), a na ostatniej tylko trzy (jedno M3 i dwa M2). Układ pokoi jest podobny, od strony galerii 
9. Fragment budynku na osiedlu Kuźniki po termomodernizacji; fot. A. Gabiśs

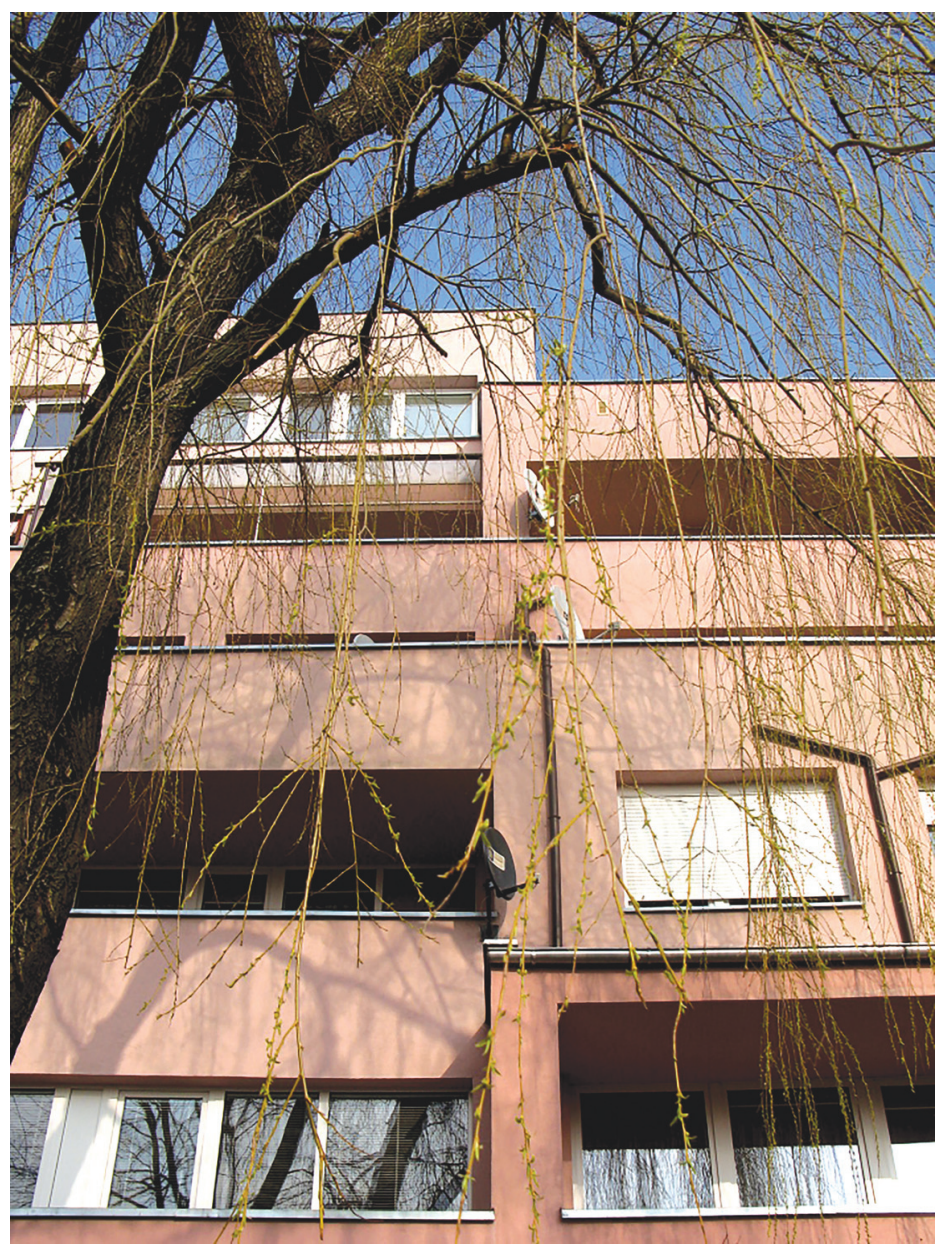

kuchnia i mniejszy pokój, łazienka umieszczona centralnie i pokój lub pokoje po drugiej stronie (o kształcie lekko wydłużonych, poziomych prostokątów). Wszystkie mieszkania mają loggie lub tarasy (na najwyższych kondygnacjach).

Te metraże i rozkłady powtórzone zostały, z pewnymi modyfikacjami, w większości budynków - wyjątek stanowią wspomniane już małe mieszkania $\mathrm{w}$ blokach $\mathrm{z}$ usługami na parterze, ale także cztery nietypowe budynki na planie zbliżonym do litery $\mathrm{C}$. W przyziemiach maja garaże, a na pierwszej kondygnacji bardzo duże mieszkania: siedem M4 (57,80 m²), jedno M5 (70,82 m²) i jedno M6 (83,50 m²). Na 
wyższych kondygnacjach liczba mieszkań się zmniejsza, ale M6 znajduje się na wszystkich. Jest to najciekawszy rozkład wnętrza, jaki zastosowano na Kuźnikach: wejście prowadzi z galerii do osobnego korytarza, z którego można przejść do pokoi po lewej i prawej stronie, a część z łazienką i przyległym pokojem ma kształt zbliżony do trapezu, znajduje się bowiem w miejscu połączenia dwóch segmentów budynku pod katem 45 stopni.

Osiedle do dziś zachowało swoja pierwotną kompozycję, nieco zniekształcona jedynie przypadkowa zabudowa na obrzeżach. W $1998 \mathrm{r}$. A. Seidel-Grzesińska pisała, że „brak dbałości o utrzymanie osiedla w należytym stanie"73. Kilkanaście lat później można zauważyć poprawę w jakości utrzymania zieleni wysokiej i niskiej oraz małej architektury, niepokojący jest natomiast stan samych budynków. Z jednej strony mieszkańcy samowolnie zabudowują lub przebudowują loggie i galerie, a z drugiej - przeprowadzona termomodernizacja i dobór kolorystyki zdecydowanie odbiegaja od stanu pierwotnego i autorskiej koncepcji projektantów. Białe ściany i ciemne cokoły są systematycznie zastępowane przez odcienie różu, seledynu i oranżu - każdy blok ma inny kolor, przez co po pierwsze zaburzona została spójność całego założenia, a po drugie zaprzepaszczono ważny i cenny efekt, jakim jest wyeksponowanie naturalnej zieleni, która jest największą zaletą okolicy.

\section{Kuźniki - osiedle idealne?}

Wacław Hryniewicz, mówiąc o Kuźnikach, twierdzi, że chciał wtedy, pod koniec lat 70., zaprojektować osiedle idealne ${ }^{74}$. I że udało się to tylko tu, w tym klinie między torami a rzeka. Na terenie leżącym w bezpośrednim sasiedztwie ogromnych placów budowy, jakimi były wtedy Nowy Dwór i Gądów-Lotnisko, czyli osiedla, które w założeniu realizowały koncepcję swobodniejszej zabudowy, tworzącej zielone wnętrza, z terenami rekreacyjnymi i pełną infrastruktura, a w efekcie pozostały nieukończone, przytłaczające skala, z kompozycją czytelna tylko w niewielkim stopniu. Kuźniki miały jednak inny punkt wyjścia - ograniczony obszar, zapis w planach o niskiej zabudowie, sasiedztwo natury i przedwojennych willi. Architekci zdawali sobie sprawę z roli istniejącej i projektowanej zieleni, bo przecież „tereny zielone $\mathrm{w}$ urbanistyce współczesnej sa jednym z zasadniczych ogniw

\footnotetext{
${ }^{73}$ A. Seidel-Grzesińska, dz. cyt.

${ }^{74} \mathrm{Z}$ wywiadu z Wacławem Hryniewiczem, październik 2014 r.
} 
kompozycji przestrzennej” ${ }^{2}$, a także z konieczności harmonijnego dopasowania nowych budynków do istniejącego kontekstu. Stąd otwarcie w kierunku Lasu Kuźnickiego i przenikanie się strefy zabudowanej z zielona, poprzez ukształtowanie terenu i zagospodarowanie przestrzeni między blokami. Natomiast stopniowanie wysokości miało, oprócz efektu plastycznego, jeszcze jedną funkcję - umożliwiało względnie łagodne przejście między starą a nową częścią Kuźnik. Najlepiej jest to widoczne z perspektywy waskkich uliczek, Morskiej lub Międzyzdrojskiej, na których końcu otwierają się widoki na niższe części bloków, będące niemal tej samej wysokości, co stare domy. Potem, w kierunku centrum osiedla wysokości lekko rosna, ale nie jest to w żaden sposób przytłaczające dla otoczenia. Te dwie, odmienne urbanistyczne tkanki dopełniają się, tworząc niejednorodna, ale harmonijna całość.

We Wrocławiu nie znajdziemy wielu podobnych przykładów kameralnej architektury wpisanej w krajobraz i w zastany kontekst. Równolegle do Kuźnik powstała na Karłowicach uzupełniajacca zabudowa przy ul. H. Kamieńskiego i M. Romanowskiego, składająca się z dwóch budynków wzniesionych w technologii WBL, o zróżnicowanych, rozrzeźbionych bryłach i nieregularnych planach, z uskokami murów, stopniowanymi wysokościami (od trzech do sześciu kondygnacji) i z podobną do kuźnickiej, biało-brązową kolorystyką ${ }^{76}$. Zróżnicowanie w planach pojawiło się też w niewielkim osiedlu przy ul. Bacciarellego na Bartoszowicach, zaprojektowanym na bardzo wymagajacym krajobrazowo terenie, w bezpośrednim sasiedztwie Odry. Segmenty budynków są przesunięte względem siebie, tworzą nieregularne, uskokowe ściany, przez co wydaja się optycznie lżejsze i lepiej wpisane w otoczenie ${ }^{77}$.

Te wszystkie koncepcje bazowały nie tylko na nowych normatywach, ale przede wszystkim na nowym podejściu do projektowania osiedli. Na początku lat 70. szeroko zaczęła być krytykowana urbanistyka poprzedniej dekady, oparta na idealistycznych założeniach Karty Ateńskiej, propagującej wolno stojące, wysokie bloki rozrzucone wśród

${ }^{75}$ Cyt. za: K. Wejchert, Elementy kompozycji urbanistycznej, Warszawa 1984, s. 224.

76 Andrzej Jurkowski twierdzi, że znał te budynki i że były one jedną z inspiracji przy projektowaniu budynków kuźnickich. Projekt tych dwóch bloków przy ul. H. Kamieńskiego 11-15/Romanowskiego 8-14 powstał w Miejskim Biurze Projektów we Wrocławiu (autorzy: Ewa Franta, Bożena Maskulanis i Jerzy Strojny). Za tę informację dziękuję dawnemu kierownikowi pracowni MBP, panu Andrzejowi Ilowowi.

77 To osiedle zaprojektowali: J. Blachowski, J. Duraj, A. Hubka; zob. O. Czerner, T. Drankowski, dz. cyt., s. 33 . 
zieleni $^{78}$. W połowie lat 60 . szlachetne założenie o powszechnym dostępie do światła, zieleni i świeżego powietrza zmaterializowało się w Polsce pod postacią długich, wielkopłytowych bloków (ze względów ekonomicznych tylko 11- i 5-kondygnacyjnych), ustawionych prostopadle lub równolegle do siebie na dużych, niezagospodarowanych działkach, oddalonych od ulic ${ }^{79}$. Taka właśnie kryzysowa wersja Karty Ateńskiej jest np. Wrocław-Południe, Gądów Mały czy Huby. Kolejne, młodsze pokolenie architektów zaczęło pracę w czasie, gdy ograniczenia normatywowe i typizacyjne zostały nieco złagodzone, a wprowadzenie PR-5 sprzyjało pierwszym eksperymentom. Projektem, który zaważył na nowym podejściu do tworzenia przestrzeni osiedlowych był warszawski Ursynów Północy (autor: Marek Budzyński z zespołem), szeroko komentowany i dyskutowany, między innymi dlatego, że po raz pierwszy podjęto przy tej okazji temat ulicy, która powinna stanowić integralną część całej kompozycji oraz próbowano zredefiniować pojęcie osiedla, które nie powinno być wyizolowana jednostka, ale fragmentem miasta ${ }^{80}$. Taki sposób myślenia widać $\mathrm{w}$ dużych wrocławskich projektach i również w mniejszych Kuźnikach, gdzie powstała siatka kompozycyjna o wyraźnych osiach oraz namiastka miejskiego centrum, czyli pasażem handlowym. Zrealizowano również niezależne mieszkania w przyziemiach, z własnymi ogródkami - to rozwiązanie pojawiło się zarówno na Ursynowie, jak i w osiedlach o mniejszej skali, np. w niewielkim, podobnym do Kuźnik zespole na Sadybie w Warszawie, projektu Andrzeja Kicińskiego ${ }^{81}$.

Witold Jerzy Molicki, charakteryzując wrocławskie osiedla przełomu lat 70. i 80., podkreślił przewagę tendencji rzeźbiarskich, zarówno

${ }^{78}$ Krytyka nie dotyczyła tylko krajów bloku wschodniego, ale całej Europy i USA, gdzie również powstawały podobne założenia. Kulminacyjnym punktem tej krytyki było wyburzenie w 1971 r. dużego osiedla Pruitt-Igoe w St Louis.

${ }^{79}$ Karta Ateńska to dokument uchwalony w 1933 r. przez CIAM (Międzynarodowy Kongres Architektury Nowoczesnej), definiujący nowe funkcje miasta i osiedla, oparte między innymi na rozdzieleniu stref pracy i mieszkania oraz ruchu samochodowego od pieszego, a także postulujący zapewnienie wszystkim mieszkańcom dostępu do zieleni, słońca i świeżego powietrza. Więcej o recepcji Karty Ateńskiej we Wrocławiu zob. A. Gabiś, Nowa Biblia - postulaty Karty Ateńskiej a wroctawskie osiedla z lat 1956-1970, w: Trwałość? Użyteczność? Piękno? Architektura dwudziestego wieku $w$ Polsce, red. A. Zabłocka-Kos, Wrocław 2011, s. 103-108.

${ }^{80}$ E. Przestaszewska-Porębska, Nowa utopia. Polska myśl urbanistyczna lat osiemdziesiatych na tle tendencji powojennych, „Architektura” 1987, nr 3, s. 4; P. Szafer, dz. cyt., s. 5-9.

81 Jest to osiedle o charakterze uzupełniajacym, z uskokami w planach i światłocieniowymi elewacjami; zob. Osiedle mieszkaniowe na Sadybie, „Architektura” 1976, nr 7-8, s. 38 . 
10. Wnętrze międzyblokowe na osiedlu Kuźniki; fot. A. Gabiś

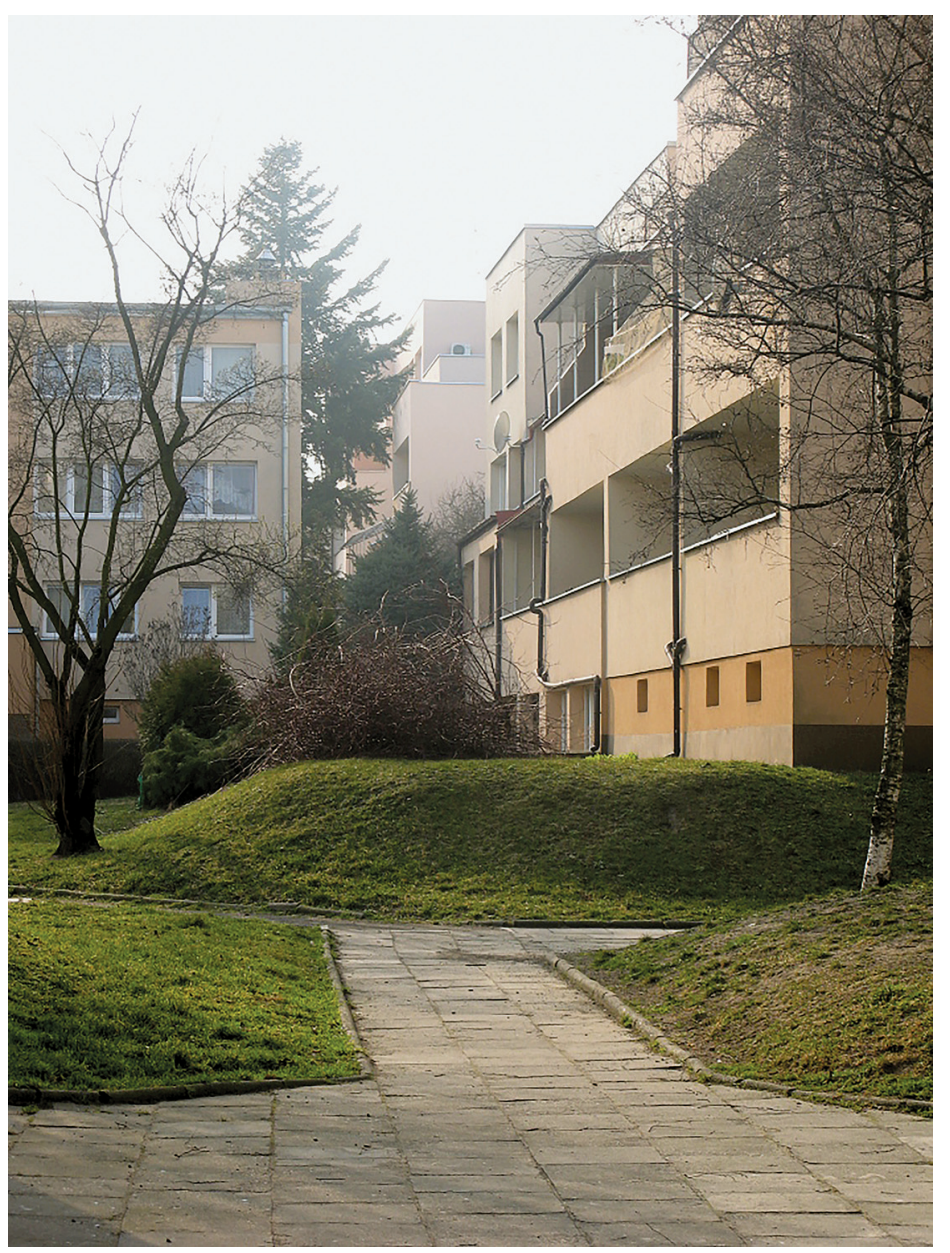

w formie samych budynków, jak i całych kompozycji przestrzennych. Docenił próby (nie zawsze uwieńczone sukcesem), jakie podjęli architekci przy projektowaniu Nowego Dworu czy Kozanowa, zastrzegając, że oceniać je należy dopiero po ukończeniu: „dzisiaj jednak możemy zasygnalizować, że osiedle Kuźniki posiada bardzo dobra skalę dla siedliska peryferyjnego" 2 . Dodać należy, że jest to skala pojawiająca się w osiedlach skandynawskich czy zachodnioniemieckich, i tym samym w peryferyjnych Kuźnikach skupia się wiele zagadnień polskiej i światowej urbanistyki, oscylującej wokół poszukiwania ludzkiej skali i harmonii z natura.

${ }^{82}$ W.J. Molicki, dz. cyt., s. 40. 
Daniela Przyłęcka twierdzi, że pomimo powtarzalności, ograniczeń technologicznych i konieczności cięcia kosztów każde wrocławskie osiedle jest inne, w każdym widać autorską koncepcję, nawet jeśli zrealizowana tylko fragmentarycznie ${ }^{83}$. Na Kuźnikach, z dala od centrum miasta, założenia projektowe są czytelne, zostały niemal w całości wcielone w życie i dlatego ,jest to może najlepsze, bardzo ludzkie w skali, lecz mało znane osiedle" 84 . Ostateczny efekt jest więc wypadkowa potrzeby eksperymentu, wrażliwości na kontekst i warunki krajobrazowe oraz urbanistycznych i ekonomicznych obostrzeń. A także wynikiem niezależnej od politycznego ustroju, wspólnej dla większości architektów chęci stworzenia „osiedla idealnego”.

\section{Bibliografia}

Antkowiak Z., Stare i nowe osiedla Wrocławia, Wrocław 1973.

Architekci Wrocławia 1945-1995. 50 lat Stowarzyszenia Architektów Polskich we Wrocławiu i na Dolnym Ślasku, wybór i oprac. materiałów J. Zasada i A. Zwierzchowski, Wrocław 1996.

Atlas Architektury Wrocławia, red. J. Harasimowicz, t. 2, Wrocław 1998.

Basista A., Betonowe dziedzictwo. Architektura w Polsce czasów komunizmu, Warszawa-Kraków 2001.

Chmielewski J.M., Teoria urbanistyki $w$ projektowaniu i planowaniu miast, Warszawa 2010.

Dąbrowska-Milewska G., Standardy urbanistyczne dla terenów mieszkaniowych - wybrane zagadnienia, „Architekturae et Artibus”, 2010, nr 1, s. $17-31$.

Drankowski T., Czerner O., Wrocław z lotu ptaka, Wrocław 1985.

Encyklopedia Wrocławia, red. J. Harasimowicz, Wrocław 2000.

Gryz R., Pozwolić czy nie? Władze PRL wobec budownictwa sakralnego $w$ latach 1971-1980, Kielce 2007.

Inwestprojekt Wroctaw. Przeglad prac projektowych do 1988 roku, Wrocław 1989

Jarosz D., Mieszkanie się należy... Studium z peerelowskich praktyk społecznych, Warszawa 2010.

Korzeniewski W., Normatyw urbanistyczny i mieszkaniowy - 1974, Warszawa 1980.

Kuminek E., Problemy programowania i projektowania, „Architektura” 1983, nr 2, s. 18-19.

Leksykon Architektury Wroctawia, red. nauk. R. Eysymontt et al., Wrocław 2011.

${ }^{83}$ D. Przyłęcka, Nie od razuu..., s. 200.

${ }^{84}$ O. Czerner, T. Drankowski, dz. cyt., s. 38. 
Lis A., Struktura przestrzenna i społeczna terenów rekreacyjnych $w$ osiedlach mieszkaniowych Wrocławia z lat 70.-80. ubiegłego stulecia, Wrocław 2011.

Madej K., Spótdzielczość mieszkaniowa. Wtadze PRL wobec niezależnej inicjatywy społecznej (1961-1965), Warszawa 2003.

Marciniak P., Doświadczenia modernizmu. Architektura i urbanistyka Poznania w czasach PRL, Poznań 2010.

Osiedle mieszkaniowe na Sadybie, „Architektura” 1976, nr 7-8.

Prętczyński Z., Pamięci architektów wrocławskich, Wrocław 2010.

Przeglad osiedli mieszkaniowych, „Architektura” 1984, nr 3.

Przestaszewska-Porębska E., Nowa utopia. Polska myśl urbanistyczna lat osiemdziesiatych na tle tendencji powojennych, „Architektura”1987, nr 3.

Przyłęcka D., Nie od razu Wrocław odbudowano. Plany zagospodarowania przestrzennego, koncepcje oraz projekty urbanistyczne $i$ architektoniczne a ich realizacja w latach 1945-1989, Wrocław 2012.

Reporter „Architektury” po wizycie we Wroctawiu, „Architektura” 1975, nr 1.

Szafer P., Nowa architektura polska. Diariusz lat 1976-1980, Warszawa 1981.

Trwatość? Użyteczność? Piękno? Architektura dwudziestego wieku w Polsce, red. A. Zabłocka-Kos, Wrocław 2011.

Wejchert K., Elementy kompozycji urbanistycznej, Warszawa 1984.

Wroctaw, jego dzieje i kultura, red. Z. Świechowski, Warszawa 1978.

Wroctawskie dworce kolejowe, red. M. Zwierz, Wrocław 2006.

Zaremba P., Rola architektury i urbanistyki $w$ rozwoju budownictwa mieszkaniowego w Polsce, „Architektura” 1976, nr 10.

\section{Agata Gabiś}

Wrocław's Kuźniki housing estate: circumstances of its creation and the analysis of the spatial and architectonic development plan

(Summary)

The 1970s was a period marked by numerous new housing investments in entire Poland, including Wrocław. In case of the town in question, these undertakings were influenced by its particular predicament, a city remaining in the constant state of reconstruction, with large land reserves available both in the centre and in the suburbs. The post-war architecture of Wrocław was dominated by housing development. Up to 1970, new estates were built on the areas improved before the outbreak of the war, with new buildings integrated into the already existent post-German street grid. Under the rule of Edward Gierek, new housing estates (including Kuźniki) were developed in the areas which had not previously been built-up, becoming a home for almost 100,000 people, while the slow pace of their construction was closely linked to the end of the boom experienced in the era of Gierek and the economic crisis of the 1980s. This period of the town's development, as well as individual 
housing estates built at the time, have not yet been the object of wide research or analysis in the urban and social context.

In the western part of Wrocław, between two big housing estates called Nowy Dwór and Gądów, in a green wedge delimited by railway tracks and the river, a team of young architects designed a small, cooperative estate equipped with all necessary services, with well-arranged surroundings and diverse architecture. Kuźniki was meant to serve as an alternative for mass-scale large panel systems and monotonous urban planning based on repetitive solutions. The final outcome is a composite of the need to experiment, awareness of the context and landscape, and of urban and economic constraints. It is also the result of the will to create "a perfect estate," independent from the political regime and common for most architects. The analysis of this relatively unknown development plan and its comparison against other housing estates provide much information on the Polish construction sector towards the end of the 1970s and on the specific conditions in Wrocław, while at the same time partially contradicting the thesis on the widespread unification dominant in the architecture of the period.

Agata Gabiś - historyk sztuki i architektury, absolwentka historii sztuki UWr, adiunkt w Zakładzie Historii Kultury Materialnej w Instytucie Historycznym UWr.; zajmuje się historią architektury XX w., ze szczególnym uwzględnieniem polskiej architektury powojennej w kontekście artystycznym, politycznym, gospodarczym i socjologicznym. Współpracuje z instytucjami upowszechniajaccymi polską sztukę i historię (Muzeum Współczesne Wrocław, Ośrodek Pamięć i Przyszłość). E-mail: agatagabis@gmail.com. 